\title{
Article \\ Abnormal Calcium Handling in Atrial Fibrillation Is Linked to Changes in Cyclic AMP Dependent Signaling
}

\author{
Franziska Reinhardt ${ }^{1,2,+}{ }^{,}$Kira Beneke ${ }^{2,3,+}$, Nefeli Grammatica Pavlidou ${ }^{2,3}$, Lenard Conradi ${ }^{1}$, \\ Hermann Reichenspurner ${ }^{1,3}$, Leif Hove-Madsen ${ }^{4}$ and Cristina E. Molina ${ }^{2,3, *(D)}$ \\ 1 Department of Cardiovascular Surgery, University Heart \& Vascular Center Hamburg UKE, \\ 20251 Hamburg, Germany; fr.reinhardt@uke.de (F.R.); 1.conradi@uke.de (L.C.); reichenspurner@uke.de (H.R.) \\ 2 German Center for Cardiovascular Research (DZHK), Partner Site Hamburg/Kiel/Lübeck, \\ 20251 Hamburg, Germany; k.beneke@uke.de (K.B.); nefeligramm@gmail.com (N.G.P.) \\ 3 Institute of Experimental Cardiovascular Research, University Medical Center Hamburg-Eppendorf (UKE), \\ 20251 Hamburg, Germany \\ 4 Biomedical Research Institute Barcelona, IIBB-CSIC and IIB Sant Pau, Hospital de la Santa Creu i Sant Pau, \\ 08025 Barcelona, Spain; leif.hove@iibb.csic.es \\ * Correspondence: c.molina@uke.de; Tel.: +49-407-4105-7095 \\ + These authors contributed equally to this work.
}

check for

updates

Citation: Reinhardt, F.; Beneke, K.; Pavlidou, N.G.; Conradi, L.;

Reichenspurner, H.; Hove-Madsen, L.;

Molina, C.E. Abnormal Calcium

Handling in Atrial Fibrillation Is

Linked to Changes in Cyclic AMP

Dependent Signaling. Cells 2021, 10,

3042. https://doi.org/10.3390/

cells10113042

Academic Editors: Ursula Ravens and Rémi Peyronnet

Received: 18 August 2021

Accepted: 2 November 2021

Published: 5 November 2021

Publisher's Note: MDPI stays neutral with regard to jurisdictional claims in published maps and institutional affiliations.

Copyright: (c) 2021 by the authors Licensee MDPI, Basel, Switzerland. This article is an open access article distributed under the terms and conditions of the Creative Commons Attribution (CC BY) license (https:/ / creativecommons.org/licenses/by/ $4.0 /)$.

\begin{abstract}
Both, the decreased L-type $\mathrm{Ca}^{2+}$ current $\left(\mathrm{I}_{\mathrm{Ca}, \mathrm{L}}\right)$ density and increased spontaneous $\mathrm{Ca}^{2+}$ release from the sarcoplasmic reticulum (SR), have been associated with atrial fibrillation (AF). In this study, we tested the hypothesis that remodeling of $3^{\prime}, 5^{\prime}$-cyclic adenosine monophosphate (cAMP)dependent protein kinase A (PKA) signaling is linked to these compartment-specific changes (upor down-regulation) in $\mathrm{Ca}^{2+}$-handling. Perforated patch-clamp experiments were performed in atrial myocytes from 53 patients with $\mathrm{AF}$ and 104 patients in sinus rhythm $(\mathrm{Ctl})$. A significantly higher frequency of transient inward currents $\left(\mathrm{I}_{\mathrm{TI}}\right)$ activated by spontaneous $\mathrm{Ca}^{2+}$ release was confirmed in myocytes from AF patients. Next, inhibition of PKA by H-89 promoted a stronger effect on the $\mathrm{I}_{\mathrm{TI}}$ frequency in these myocytes compared to myocytes from Ctl patients (7.6-fold vs. 2.5 -fold reduction), while the $\beta$-agonist isoproterenol (ISO) caused a greater increase in Ctl patients (5.5-fold vs. 2.1-fold). $\mathrm{I}_{\mathrm{Ca}, \mathrm{L}}$ density was larger in myocytes from $\mathrm{Ctl}$ patients at baseline $(p<0.05)$. However, the effect of ISO on $\mathrm{I}_{\mathrm{Ca}, \mathrm{L}}$ density was only slightly stronger in AF than in Ctl myocytes (3.6-fold vs. 2.7-fold). Interestingly, a significant reduction of $\mathrm{I}_{\mathrm{Ca}, \mathrm{L}}$ and $\mathrm{Ca}^{2+}$ sparks was observed upon $\mathrm{Ca}^{2+} /$ Calmodulin-dependent protein kinase II inhibition by $\mathrm{KN}-93$, but this inhibition had no effect on $\mathrm{I}_{\mathrm{TI}}$. Fluorescence resonance energy transfer (FRET) experiments showed that although AF promoted cytosolic desensitization to $\beta$-adrenergic stimulation, ISO increased cAMP to similar levels in both groups of patients in the L-type $\mathrm{Ca}^{2+}$ channel and ryanodine receptor compartments. Basal cAMP signaling also showed compartment-specific regulation by phosphodiesterases in atrial myocytes from $44 \mathrm{Ctl}$ and $43 \mathrm{AF}$ patients. Our results suggest that $\mathrm{AF}$ is associated with opposite changes in compartmentalized PKA/cAMP-dependent regulation of $\mathrm{I}_{\mathrm{Ca}, \mathrm{L}}$ (down-regulation) and $\mathrm{I}_{\mathrm{TI}}$ (up-regulation).
\end{abstract}

Keywords: atrial fibrillation (AF); cAMP-dependent regulation; protein kinase A (PKA); L-type calcium current $\left(\mathrm{I}_{\mathrm{Ca}, \mathrm{L}}\right)$; transient inward current $\left(\mathrm{I}_{\mathrm{TI}}\right)$; patch-clamp

\section{Introduction}

Atrial fibrillation (AF) has been commonly associated with profound remodeling of calcium $\left(\mathrm{Ca}^{2+}\right)$-handling and regulatory proteins [1-4]. Thus, AF-myocytes displayed a reduced L-type $\mathrm{Ca}^{2+}$ current $\left(\mathrm{I}_{\mathrm{Ca}, \mathrm{L}}\right)$ density $[2,5,6]$, as well as an increased spontaneous sarcoplasmic reticulum (SR) $\mathrm{Ca}^{2+}$ release [1] through the ryanodine receptor (RyR2) called $\mathrm{Ca}^{2+}$ sparks and $\mathrm{Ca}^{2+}$ waves. The increased $\mathrm{Ca}^{2+}$ waves then resulted in a rise in concurrent transient inward current $\left(\mathrm{I}_{\mathrm{TI}}\right)$, due to $\mathrm{Ca}^{2+}$ extrusion by the $\mathrm{Na}^{+}-\mathrm{Ca}^{2+}$ exchanger (NCX) [7], and the corresponding additional depolarization of the membrane. 
A common mechanism proposed to explain $\mathrm{Ca}^{2+}$-handling remodeling is a change in the phosphorylation state of the related proteins [3,8-10]. Two distinct serine residues of RyR2 have displayed increased phosphorylation in AF. The first one, ser2809 (ser2808 in rodents) $[3,5,6]$, has been shown to be phosphorylated by protein kinase A (PKA). $3^{\prime}, 5^{\prime}$ Cyclic adenosine monophosphate (cAMP)-dependent activation of PKA is indeed a major pathway for modulation of protein phosphorylation. cAMP levels are in turn regulated by adenylyl cyclases (AC), which generate cAMP upon G protein-coupled receptor stimulation by catecholamines, and by phosphodiesterases (PDEs), which degrade cAMP and regulate its propagation, mediating compartmentalized cAMP signals [4]. Additionally, the reduced $\mathrm{I}_{\mathrm{Ca}, \mathrm{L}}$ density has been shown to be in part linked to a phosphatase-dependent reduction in the phosphorylation state of the L-type $\mathrm{Ca}^{2+}$ channel [11]. The second one, ser2815 (ser2814 in rodents), has been shown to be phosphorylated by $\mathrm{Ca}^{2+} /$ Calmodulin-dependent protein kinase II (CaMKII) [6,10]. CaMKII activity is actively regulated by $\mathrm{Ca}^{2+}$, calmodulin and phosphatases. Furthermore, intracellular increase in cAMP levels can also activate a guanine nucleotide exchange factor, the exchange protein activated by cAMP (Epac) [12], and phosphorylate RyR2 via CaMKII in a PKA-independent manner [13].

Therefore, remodeling of the phosphorylation state of $\mathrm{Ca}^{2+}$ regulatory proteins is emerging as an important mechanism modulating abnormal $\mathrm{Ca}^{2+}$ handling in $\mathrm{AF}$. However, these findings suggest opposite modulatory phosphorylation states between the RyR2 [3,5] and the L-type $\mathrm{Ca}^{2+}$ channel [9], making it important to determine if this is due to alterations or compartmentalization of the regulating phosphorylation pathways.

This study, therefore, tested the hypothesis that the remodeling of L-type $\mathrm{Ca}^{2+}$ current and SR $\mathrm{Ca}^{2+}$ channel activity in AF is due to changes in cAMP-dependent PKA signaling, the key pathway for $\beta$-adrenergic receptor-mediated regulation of the phosphorylation state of these channels. Hence, the effect of the pharmacological manipulation of cAMPdependent signaling on $\mathrm{I}_{\mathrm{Ca}, \mathrm{L}}$ density, frequency of $\mathrm{SR} \mathrm{Ca}^{2+}$ release events large enough to produce $\mathrm{I}_{\mathrm{TI}}$ and cAMP levels was investigated in atrial myocytes from patients in sinus rhythm (Ctl) and with AF. Specifically, PKA and CaMKII were inhibited to eliminate PKA and CaMKII-dependent $\mathrm{Ca}^{2+}$ channel phosphorylation, and $\beta$-adrenergic signaling was stimulated to maximize $\mathrm{Ca}^{2+}$ channel phosphorylation.

Our data show that in AF, PKA-inhibition with $\mathrm{H}-89$ had little effect on the $\mathrm{I}_{\mathrm{Ca}, \mathrm{L}}$ amplitude, but strongly reduced spontaneous $\mathrm{Ca}^{2+}$ release large enough to produce spontaneous transient inward currents. These results suggest that, opposite to sinus rhythm, PKA-dependent phosphorylation is minimal for the L-type $\mathrm{Ca}^{2+}$ channel but eminent for the RyR2 at baseline in AF patients. However, $\beta$-adrenergic stimulation with isoprenaline increased $\mathrm{I}_{\mathrm{Ca}, \mathrm{L}}$ amplitude, $\mathrm{I}_{\mathrm{TI}}$ and cAMP levels in all compartments in both groups of patients. Therefore, changes in $\mathrm{Ca}^{2+}$ handling seen in patients with AF are likely due to modulations in cAMP-dependent regulation.

\section{Materials and Methods}

\subsection{Human Atrial Samples}

A total of 244 atrial human tissue samples were collected from patients undergoing cardiac surgery at the University Heart and Vascular Center Hamburg-Eppendorf (UKE). Atrial tissues were taken from patients in sinus rhythm $(\mathrm{Ctl})$ or with atrial fibrillation $(\mathrm{AF})$, subjected to atrial cannulation for extracorporeal circulation. All samples were taken with informed consent of the donors. The study was conducted in accordance with the Declaration of Helsinki principles and approved by the Ethical Committees of the Ärztekammer Hamburg (Ethical approval Number: WF-088/18, 26 February 2019).

Patients treated with $\mathrm{Ca}^{2+}$ antagonists were excluded from the study. Overall patient characteristics, including diagnostics and treatment were summarized in Table 1. 
Table 1. Clinical and pharmacological details of patient included in this study. Continuous variables are presented as mean \pm SD for normal-distributed data. Categorical data are given as number of patients (\%).

\begin{tabular}{|c|c|c|}
\hline Characteristics & Sinus Rhythm (Ctl) & Atrial Fibrillation (AF) \\
\hline Patients $(n)$ & 148 & 96 \\
\hline Age (years) & $60 \pm 12$ & $66 \pm 14$ \\
\hline Female $(n(\%))$ & $40(27.0)$ & $50(52.1)$ \\
\hline Arterial hypertension $(n(\%))$ & $91(61.5)$ & $53(55.2)$ \\
\hline Diabetes mellitus $(n(\%))$ & $35(23.7)$ & $30(31.2)$ \\
\hline Dyslipemia $(n(\%))$ & $52(35.1)$ & $37(38.5)$ \\
\hline \multicolumn{3}{|l|}{ Indication for surgery } \\
\hline Coronary artery disease $(n(\%))$ & $48(32.4)$ & $11(11.5)$ \\
\hline Valvular heart disease $(n(\%))$ & $70(47.3)$ & $80(83.3)$ \\
\hline Both $(n(\%))$ & $30(20.3)$ & $5(5.2)$ \\
\hline \multicolumn{3}{|l|}{ Echocardiography data } \\
\hline Left atrial diameter (mm) & $44 \pm 9$ & $51 \pm 11$ \\
\hline $\operatorname{LVEF}(\%)$ & $59 \pm 8$ & $58 \pm 11$ \\
\hline \multicolumn{3}{|l|}{ Medication } \\
\hline ACE inhibitor $(n(\%))$ & $50(33.8)$ & $39(40.6)$ \\
\hline $\mathrm{AT}_{1}$ receptor antagonist $(n(\%))$ & $44(29.7)$ & $46(47.9)$ \\
\hline$\beta$-blocker $(n(\%))$ & $31(20.9)$ & $48(50.0)$ \\
\hline Statins $(n(\%))$ & $56(37.8)$ & $29(30.2)$ \\
\hline Amiodarone $(n(\%))$ & $0(0)$ & $29(30.2)$ \\
\hline Diuretics $(n(\%))$ & $32(21.6)$ & $66(68.7)$ \\
\hline Digitalis $(n(\%))$ & $54(36.5)$ & $29(30.2)$ \\
\hline Nitrates $(n(\%))$ & $1(0.7)$ & $6(6.2)$ \\
\hline
\end{tabular}

1Abbreviations: LVEF: left ventricular ejection fraction, ACE inhibitor: angiotensin-converting enzyme inhibitor, $\mathrm{AT}_{1}$ receptor antagonist: angiotensin II receptor type 1 blockers. $\mathrm{N}$-numbers represent number of patients whose samples were used for cell isolation and afterwards on patch-clamp recording and/or confocal and/or fluorescence resonance energy transfer experiments.

\subsection{Isolation and Culture of Human Atrial Myocytes}

A total of 428 human atrial myocytes from 148 patients in sinus rhythm and 96 patients with AF were isolated as previously described $[14,15]$ and used for experiments in this study. Right atrial appendage tissue samples, normally discarded during surgery, were cut into small pieces of tissue, and incubated at $35{ }^{\circ} \mathrm{C}$ in a $\mathrm{Ca}^{2+}$ free solution containing $0.5 \mathrm{mg} / \mathrm{mL}$ collagenase (Worthington type 2, $323 \mathrm{U} / \mathrm{mg}$; Lakewood, NJ, USA), $0.5 \mathrm{mg} / \mathrm{mL}$ proteinase (Sigma type XXIV, $11 \mathrm{U} / \mathrm{mg}$ solid; St. Louis, MO, USA) and $2 \%$ bovine serum albumin (BSA; Sigma, St. Louis, MO, USA). After $30 \mathrm{~min}$, the tissue was removed from the enzyme solution, and cells were disaggregated with a Pasteur pipette in $\mathrm{Ca}^{2+}$-free solution containing $5 \%$ BSA and $2 \mu \mathrm{M}$ blebbistatin (Sigma, St. Louis, MO, USA). The remaining tissue was digested for $3 \times 15 \mathrm{~min}$ in a fresh $\mathrm{Ca}^{2+}$ free solution containing $0.4 \mathrm{mg} / \mathrm{mL}$ collagenase and $2 \%$ BSA. Freshly isolated cells were suspended in $\mathrm{Ca}^{2+}$-free solution containing $5 \%$ BSA for patch-clamp experiments (duration $\approx 8 \mathrm{~h}$ ) or in minimal essential medium (MEM: M 4780; Sigma, St. Louis, MO, USA) containing $1.2 \mathrm{mmol} / \mathrm{L} \mathrm{Ca}^{2+}, 2.5 \%$ fetal bovine serum (FBS, Invitrogen, Cergy-Pontoise, France), 1\% penicillin-streptomycin, $2 \%$ HEPES and $2 \mu \mathrm{M}$ blebbistatin (pH 7.6) and plated on $35 \mathrm{~mm}$, laminin-coated culture dishes (10 $\mu \mathrm{g} / \mathrm{mL}$ laminin, $2 \mathrm{~h}$; Sigma, St. Louis, MO, USA) for fluorescence resonance energy transfer (FRET) experiments. After $2 \mathrm{~h}$ of culture, the medium was replaced by $2 \mathrm{~mL}$ of FBS-free MEM with $2 \mu \mathrm{M}$ blebbistatin. All experiments were performed at room temperature. Only elongated cells with clear cross striations and without granulation were used for experiments.

\subsection{Patch-Clamp Technique}

Spontaneous $\mathrm{I}_{\mathrm{TI}}$, caffeine-induced NCX currents and $\mathrm{I}_{\mathrm{Ca}, \mathrm{L}}$ were measured using a perforated patch-clamp technique in freshly isolated myocytes as previously described [1] 
A HEKA EPC-10 amplifier (HEKA Elektronik GmbH, Lambrecht, Germany) was used to measure $\mathrm{I}_{\mathrm{Ca}, \mathrm{L}}$ elicited by a $200 \mathrm{~ms}$ depolarization from -80 to $0 \mathrm{mV}$ and the tail currents activated upon repolarization to $-80 \mathrm{mV}$ at a pacing frequency of $2 \mathrm{~Hz}$. The $\mathrm{I}_{\mathrm{Ca}, \mathrm{L}}$ amplitude was determined as the difference between the peak inward current and the current level at the end of a $200 \mathrm{~ms}$ depolarization pulse. $\mathrm{Na}^{+}$currents were eliminated by a $50 \mathrm{~ms}$ pre-pulse to $-50 \mathrm{mV}$. $\mathrm{I}_{\mathrm{TI}}$ currents were measured at $-80 \mathrm{mV}$ and the spontaneous $\mathrm{I}_{\mathrm{TI}}$ frequency was used to measure $\mathrm{Ca}^{2+}$ waves induced by spontaneous $\mathrm{SR} \mathrm{Ca}^{2+}$ release [7]. $\mathrm{SR} \mathrm{Ca}^{2+}$ load was measured using the NCX current time integral elicited by a rapid application of $10 \mathrm{mmol} / \mathrm{L}$ caffeine [16], assuming a stoichiometry of $1 \mathrm{Ca}^{2+}: 3 \mathrm{Na}^{+}$for the NCX. Series resistance compensation was not performed. The extracellular medium $(\mathrm{pH}=7.4)$ contained: $\mathrm{NaCl}$ $127 \mathrm{mM}$, TEA $5 \mathrm{mM}$, HEPES $10 \mathrm{mM}, \mathrm{NaHCO}_{3} 4 \mathrm{mM}, \mathrm{NaH}_{2} \mathrm{PO}_{4} 0.33 \mathrm{mM}$, glucose $10 \mathrm{mM}$, pyruvic acid $5 \mathrm{mM}, \mathrm{CaCl}_{2} 2 \mathrm{mM}$, and $\mathrm{MgCl}_{2} 1.8 \mathrm{mM}$. The intracellular medium ( $\mathrm{pH}=7.2$ with $\mathrm{CsOH}$ ) contained: aspartic acid $109 \mathrm{mM}, \mathrm{CsCl} 47 \mathrm{mM}, \mathrm{Mg}_{2}$ ATP $3 \mathrm{mM}, \mathrm{MgCl}_{2} 1 \mathrm{mM}$, $\mathrm{Na}_{2}$ phosphocreatine $5 \mathrm{mM}, \mathrm{Li}_{2} \mathrm{GTP} 0.42 \mathrm{mM}$, HEPES $10 \mathrm{mM}$ and $250 \mu \mathrm{g} / \mathrm{mL}$ amphotericin $\mathrm{B}$.

\subsection{Confocal Calcium Imaging}

Freshly isolated intact myocytes were loaded with a fluorescent $\mathrm{Ca}^{2+}$ dye $(2.5 \mu \mathrm{M}$ fluo-4 AM) for 20 min under control Tyrode perfusion (in mmol/L): $140 \mathrm{NaCl}, 4 \mathrm{KCl}$, $1.1 \mathrm{MgCl}_{2}, 10$ HEPES, 10 glucose, $1.8 \mathrm{CaCl}_{2} ; \mathrm{pH}=7.4$, with $\mathrm{NaOH}$ ). $\mathrm{Ca}^{2+}$ imaging was carried out with and a 63x glycerol-immersion objective and a resonance scanning Leica TCS SP8 X microscope (Leica Biosystems, Wetzlar, Germany) in the frame scanning mode at a frame rate of $90 \mathrm{~Hz}$, with images being acquired every $30 \mathrm{~s}$. Fluo-4 (Invitrogen, MA, USA) was excited at $488 \mathrm{~nm}$ and fluorescence emission measured between 500 and $650 \mathrm{~nm}$. Image analysis was performed using IDL software (version 7.0.6, Research System Inc., Boulder, $\mathrm{CO}$, USA). Images were corrected for the background fluorescence. The fluorescence values (F) were normalized by the basal fluorescence $\left(\mathrm{F}_{0}\right)$ in order to obtain the fluorescence ratio $\left(\mathrm{F} / \mathrm{F}_{0}\right)$. Analysis to identify $\mathrm{Ca}^{2+}$ sparks was carried out using an automated detection system and a criterion that limited the detection of false events while detecting most $\mathrm{Ca}^{2+}$ sparks [17].

\subsection{Fluorescence Resonance Energy Transfer (FRET)-Based Live Cell Imaging of Intracellular cAMP}

FRET measurements were performed on human atrial myocytes $48 \mathrm{~h}$ after transduction with the adenovirus encoding Epac1-camps [18], pm-Epac1 [19] and Epac1-JNC [20]. A $\mathrm{K}^{+}$-Ringer solution containing: $144 \mathrm{mM} \mathrm{NaCl}, 5.4 \mathrm{mM} \mathrm{KCl}, 1 \mathrm{mM} \mathrm{MgCl} 2,1 \mathrm{mM} \mathrm{CaCl}_{2}$, 10 mM HEPES, adjusted to $7.4 \mathrm{pH}$ with $\mathrm{NaOH}$ at room temperature (RT) was used to maintain cells, and images were taken every $5 \mathrm{~s}$. The FRET system used consisted of a standard inverted microscope (Leica DMI3000, Leica Biosystems, Wetzlar, Germany) with a $63 \times / 1.4$ oil immersion objective, an LED light source (pE-100, CoolLED), a beam splitter (DV2, Photometrics, Birmingham, UK), and a camera (CMOS camera optiMOS, Photometrics, Birmingham, UK). A single-wavelength light-emitting diode (LED, $440 \mathrm{~nm}$ ) was used to excite the donor fluorophore (CFP), which was controlled by an Arduino digital-to-analog input-output board (Arduino). A dual view beam splitter (Cube 05-EM, 505 dcxr, D480/30m, D535/40) was used to split the emission light into donor (CFP) and acceptor (YFP) channels.

The fluorescence emitted was then measured at $475 / 30 \mathrm{~nm}$ and $527 / 40 \mathrm{~nm}$, for CFP and YFP respectively and expressed the percent of $475 / 527 \mathrm{~nm}$. To acquire time-lapse images the software Micro-Manager 1.4.5 [21] was used. Data analysis was performed using Microsoft Excel (version 16.4, 20121301).

\subsection{Data Analysis and Statistics}

Values were expressed as means \pm SEM, and a two-tailed student's t-test used to assess significant differences between data pairs with a significance value of $p<0.05$. ANOVA was used for multiple effects comparison, whereas the Student-Newman-Keuls post-test was used to evaluate specific effects. Experimenters were blinded to clinical information. 


\section{Results}

3.1. cAMP-Dependent Regulation of L-Type $\mathrm{Ca}^{2+}$ Current and Spontaneous SR $\mathrm{Ca}^{2+}$ Release Show Opposite Changes in Atrial Fibrillation

In agreement with previous studies [1,2,6], myocytes from patients with AF had a significantly smaller $\mathrm{I}_{\mathrm{Ca}, \mathrm{L}}$ density and a higher $\mathrm{I}_{\mathrm{TI}}$ frequency at baseline. Furthermore, SR $\mathrm{Ca}^{2+}$ loading was similar for both patient groups. Next, the effects of the PKA-inhibitor $\mathrm{H}-89(10 \mu \mathrm{M})$ at baseline were tested to determine if the changes in $\mathrm{I}_{\mathrm{Ca}, \mathrm{L}}$ density or $\mathrm{I}_{\mathrm{TI}}$ frequency could be associated with changes in cAMP-dependent PKA signaling. In AFmyocytes $\mathrm{I}_{\mathrm{Ca}, \mathrm{L}}$ density was comparable before and after exposure to H-89, yet notably in $\mathrm{Ctl}$ myocytes $\mathrm{I}_{\mathrm{Ca}, \mathrm{L}}$ density was significantly reduced to levels seen in AF myocytes (Figure 1a). Inhibition with H-89 induced a small shift to the right on the current-voltage (IV) relationship after $\mathrm{H}-89$ treatment in AF myocytes (Figure $1 \mathrm{~b}$ ). The $\mathrm{I}_{\mathrm{TI}}$ current frequency was practically abolished in both patient groups by H-89 (Figure 1c), although no effect was observed on $\mathrm{Ca}^{2+}$ sparks frequency or density (Figure 1d). Indeed, the inhibition of $\mathrm{I}_{\mathrm{TI}}$ by $\mathrm{H}-89$ was observed to be relatively stronger in patients with AF (7.6-fold), than Ctl ones (2.5-fold), indicating that the activation of RyR2 is more dependent on PKA at baseline in myocytes from AF patients. Jointly, these results suggest cAMP compartmentation which promoted a PKA-dependent $\mathrm{I}_{\mathrm{Ca}, \mathrm{L}}$ activation at baseline in $\mathrm{Ctl}$ patients, which is not seen in patients with AF, and a PKA-dependent RyR2 activation at baseline in AF patients, which could contribute, together with other factors, to the enhanced RyR2 activity in AF.

\subsection{CaMKII Inhibition Reduces $I_{C a, L}$ and $\mathrm{Ca}^{2+}$ Sparks but Not $I_{T I}$ Frequency}

To assess whether the observed changes in intracellular $\mathrm{Ca}^{2+}$-handling were also modulated by CaMKII-dependent regulation, the effects of the CaMKII inhibitor KN$93(1 \mu \mathrm{M})$ and its inactive analog KN-92 $(1 \mu \mathrm{M})$ were investigated. I $\mathrm{I}_{\mathrm{Ca}, \mathrm{L}}$ density was significantly reduced in response to KN-93 in myocytes from AF and Ctl patients $(p=0.05$ and $p<0.005$ respectively) (Figure $2 \mathrm{a}$ ) without the I-V relationship being affected (results not shown). Neither KN-92 nor KN-93 had a significant effect on spontaneous $\mathrm{I}_{\mathrm{TI}}$ frequency in the same myocytes (Figure 2b). However, CaMKII inhibition with KN-93 significantly reduced $\mathrm{Ca}^{2+}$ spark density and frequency in $\mathrm{AF}(p<0.0001)$ (Figure $\left.2 \mathrm{c}\right)$, as well as the SR $\mathrm{Ca}^{2+}$ load (Figure S2).

\section{3. $\beta$-Adrenergic Stimulates $I_{C a, L}$ Equally in $C t l$ and AF Patients but Has a Relatively Smaller Effect on $I_{T I}$ Frequency in $A F$}

To evaluate whether $\beta$-adrenergic signaling was affected in AF, myocytes from $\mathrm{Ctl}$ and AF patients were exposed to the $\beta$-adrenergic agonist isoproterenol (ISO) (100 nM). As shown in Figure $3 a, b$, ISO promoted a relative similar increase in $\mathrm{I}_{\mathrm{Ca}, \mathrm{L}}$ density in myocytes from both groups of patients (2.7-fold in Ctl vs. 3.6-fold in AF). However, superimposed current traces before and after ISO exposure shown in Figure 3a (left panel) highlight that $\mathrm{I}_{\mathrm{Ca}, \mathrm{L}}$ amplitude in patients with AF remained smaller in absolute terms after $\beta$-adrenergic stimulation with ISO compared to $\mathrm{Ctl}$ (right panel). Additionally, ISO caused a significant negative shift in the I-V relationship in both groups $(p<0.001$ in both $\mathrm{Ctl}$ and AF) (Figure 3b).

ISO eliminated the observed differences in $\mathrm{I}_{\mathrm{TI}}$ frequency (Figure 3c) and $\mathrm{I}_{\mathrm{TI}}$ amplitude (Figure S1) among $\mathrm{Ctl}$ and AF myocytes. This means that, in relative terms, the stimulatory effect of ISO on the spontaneous $\mathrm{I}_{\mathrm{TI}}$ frequency was smaller in myocytes from patients with AF (2.1-fold) than from Ctl patients (5.5-fold).

To assess whether this effect was secondary to effects on SR $\mathrm{Ca}^{2+}$ loading or $\mathrm{Na}^{+}-\mathrm{Ca}^{2+}$ exchanger (NCX) activity, a protocol for caffeine-induced $\mathrm{Ca}^{2+}$ release from the SR was used to elicit the $\mathrm{Ca}^{2+}$ load in basal and upon ISO stimulation. Thus, the SR $\mathrm{Ca}^{2+}$ content was cleared with a brief caffeine pulse before reloading the SR during 30 stimulation pulses. Representative traces of caffeine-induced NCX-currents recorded before and after ISO exposure can be seen in Figure 3d. Myocytes from both patient groups showed the same ability to load $\mathrm{Ca}^{2+}$ into the SR before ISO treatment (Figure 3d), and similar increased reloading capability after ISO. Noticeably, the relative effect of ISO was not significantly 
different in myocytes from $\mathrm{Ctl}$ and patients with AF. The time constant (tau) for the decay of the NCX-current upon caffeine was also comparable in myocytes from $\mathrm{Ctl}$ and $\mathrm{AF}$ patients at basal and upon ISO stimulation (Figure 3e).

a
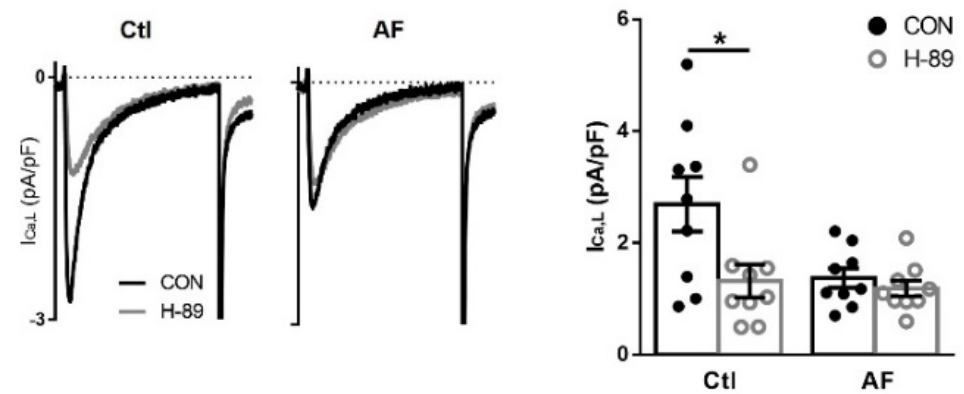

b

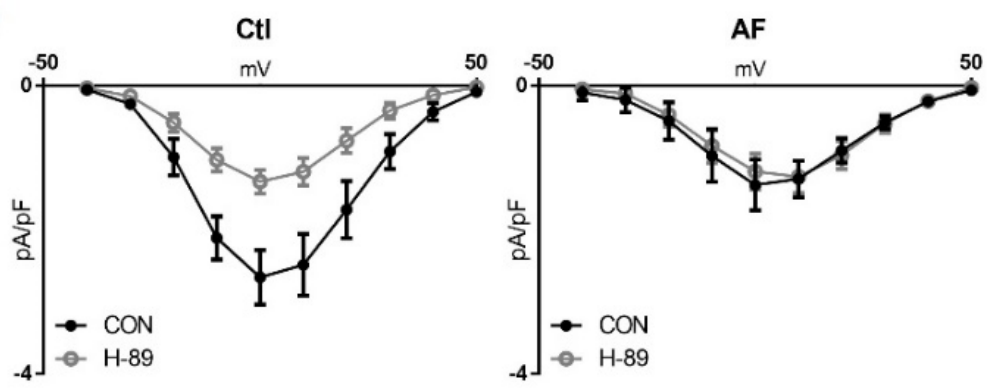

C
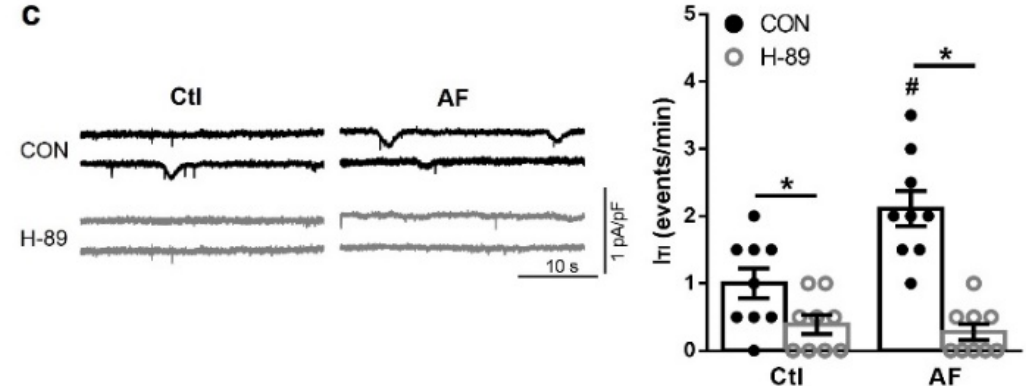

d
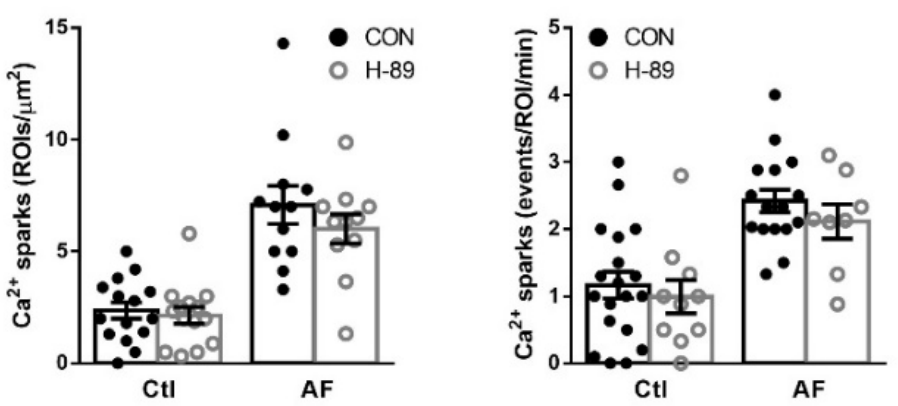

Figure 1. Effect of protein kinase A (PKA) inhibition on $\mathrm{I}_{\mathrm{Ca}, \mathrm{L}}, \mathrm{I}_{\mathrm{TI}}$ and sarcoplasmic reticulum (SR) $\mathrm{Ca}^{2+}$ load. (a) (left): Representative $\mathrm{I}_{\mathrm{Ca}, \mathrm{L}}$ recordings in myocytes from a patient in sinus rhythm $(\mathrm{Ctl})$ and a patient with atrial fibrillation (AF) before (CON, black trace) and after exposure to the selective PKA inhibitor (H-89, $10 \mu \mathrm{M}$, grey trace). (right): Average effect of $\mathrm{H}-89$ in Ctl and AF patients. (b) Mean effect of $\mathrm{H}-89$ on the current-voltage relationship in Ctl and AF patients. (c) (left): Representative traces of spontaneous $\mathrm{I}_{\mathrm{TI}}$ recorded in $\mathrm{Ctl}$ and $\mathrm{AF}$ myocytes before and after exposure to $\mathrm{H}-89$. (right): Mean effects of $\mathrm{H}-89$ on the spontaneous $\mathrm{I}_{\mathrm{TI}}$ frequency in $\mathrm{Ctl}$ and $\mathrm{AF}$ patients. (d) Average effects of $\mathrm{H}-89$ on $\mathrm{Ca}^{2+}$ sparks density (left) and frequency (right) before and after exposure to H-89. ROI: region of interest. Significant differences between treatments are indicated with * and between groups with \#. 
a

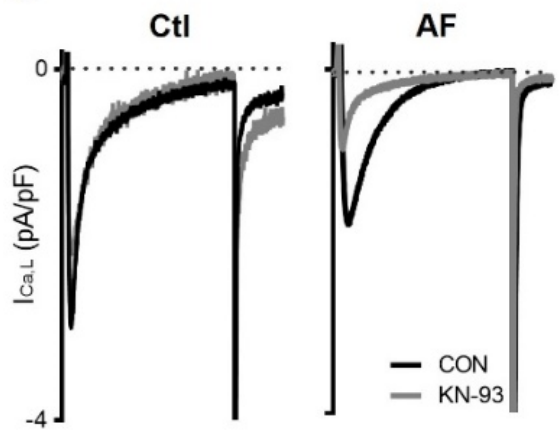

b
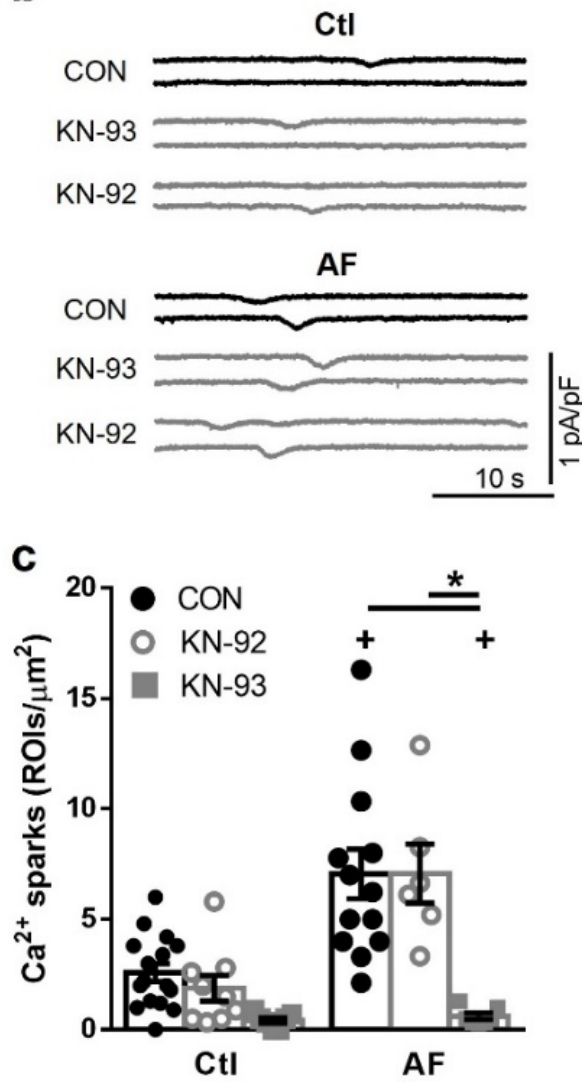
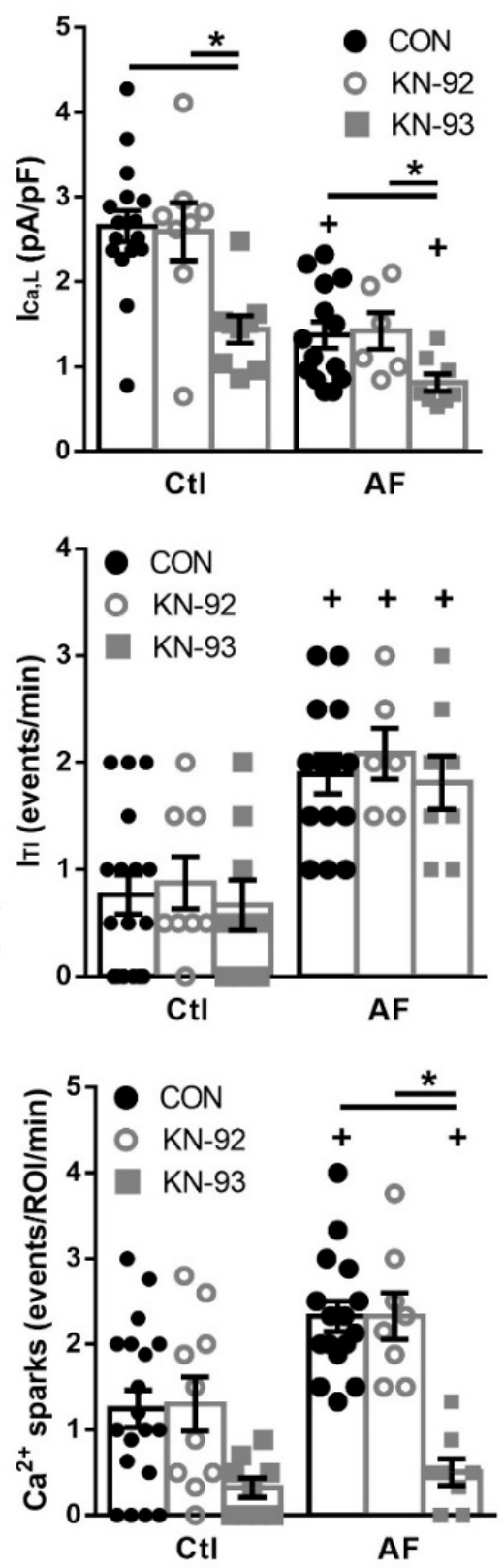

Figure 2. Effects of $\mathrm{Ca}^{2+} /$ Calmodulin-dependent protein kinase II (CaMKII) inhibition on $\mathrm{I}_{\mathrm{Ca}, \mathrm{L}}$, $\mathrm{I}_{\mathrm{TI}}$ and $\mathrm{Ca}^{2+}$ sparks. (a) (left): Representative $\mathrm{I}_{\mathrm{Ca}, \mathrm{L}}$ recordings in myocytes from a patient in sinus rhythm (Ctl) and a patient with atrial fibrillation ( $\mathrm{AF}$ ) before (CON, black trace) and after exposure to a selective CaMKII inhibitor (KN-93, $1 \mu \mathrm{M}$, grey trace). (right): Average effects of KN-92 (1 $\mu \mathrm{M}$, the inactive CaMKII inhibitor) and $\mathrm{KN}-93$ in Ctl and AF patients. (b) (left): Representative recordings of spontaneous $\mathrm{I}_{\mathrm{TI}}$ before and after exposure to $\mathrm{KN}-92$ and $\mathrm{KN}-93$ in myocytes from in $\mathrm{Ctl}$ and $\mathrm{AF}$ patients. (right): Average effects of KN-92 and KN-93 on the spontaneous $\mathrm{I}_{\mathrm{TI}}$ frequency in $\mathrm{AF}$ and Ctl myocytes. (c) Average effects of KN-92 and KN-93 on $\mathrm{Ca}^{2+}$ sparks density (left) and frequency (right) before and after exposure to KN-92 and KN-93. Significant differences between treatments are indicated with * and between groups with + . 
a

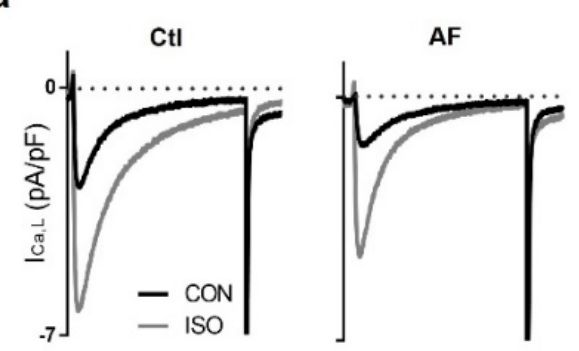

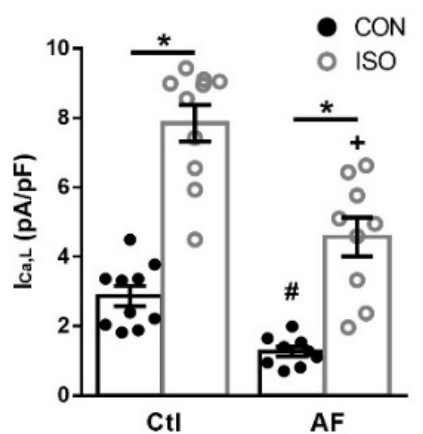

b

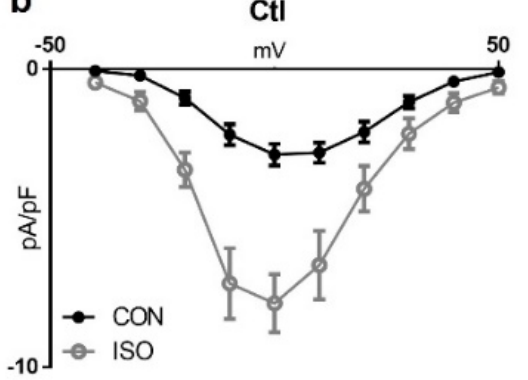

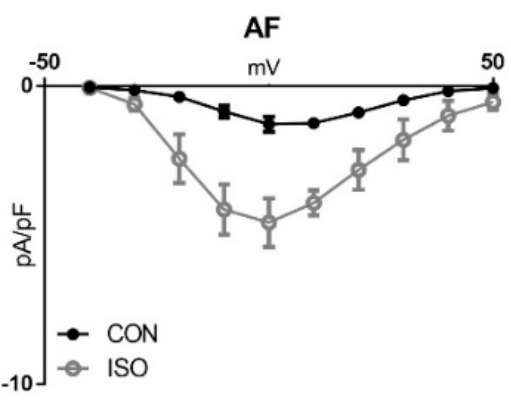

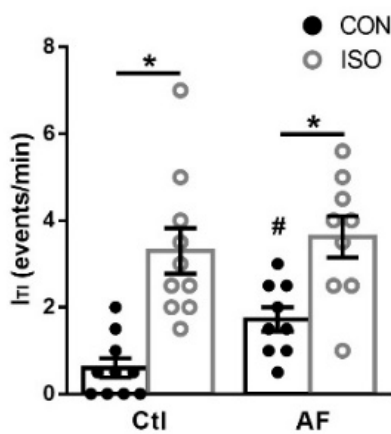

ISO

d

C

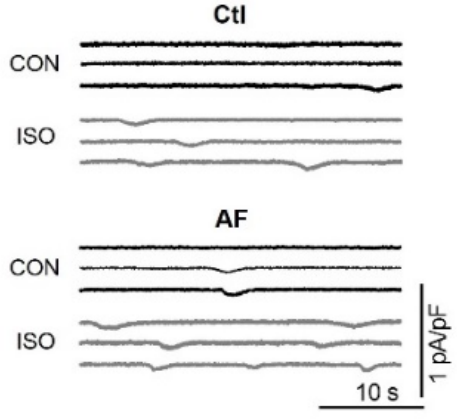

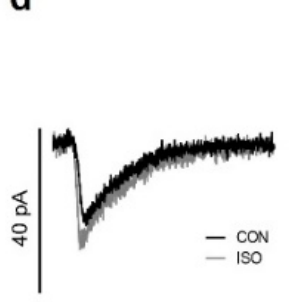

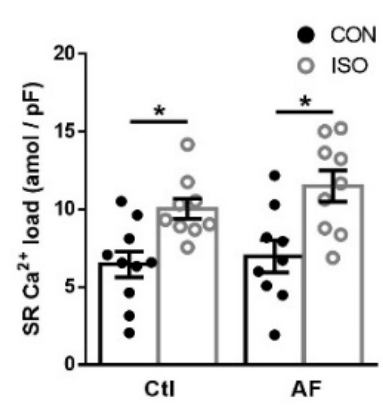

e

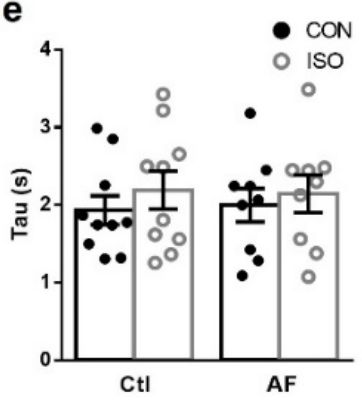

Figure 3. Effect of $\beta$-adrenergic stimulation on $\mathrm{I}_{\mathrm{Ca}, \mathrm{L}}, \mathrm{I}_{\mathrm{TI}}$ and sarcoplasmic reticulum (SR) $\mathrm{Ca}^{2+}$ load. (a) (left): Representative $\mathrm{I}_{\mathrm{Ca}, \mathrm{L}}$ recordings in myocytes from a sinus rhythm $(\mathrm{Ctl})$ patient and a patient with atrial fibrillation (AF), before (CON, black trace) and after exposure of the myocyte to $30 \mathrm{nM}$ isoproterenol (ISO, grey trace). (right): Average effects of ISO in Ctl and AF patients. (b) Mean current-voltage relationship for $\mathrm{I}_{\mathrm{Ca}, \mathrm{L}}$ in $\mathrm{Ctl}$ and $\mathrm{AF}$ myocytes before and after exposure to ISO. (c) (left): Representative recordings of $\mathrm{I}_{\mathrm{TI}}$ before and after ISO in Ctl and AF. (right): Average effects of ISO on $\mathrm{I}_{\mathrm{TI}}$ in $\mathrm{Ctl}$ and AF myocytes. (d) (right): Representative recordings of caffeine-induced NCXcurrents before and after ISO. (left): Average ISO effect on $\mathrm{SR} \mathrm{Ca}^{2+}$ load in $\mathrm{Ctl}$ and AF. (e) Average ISO effect on time constant (Tau) in Ctl and AF. Significant differences between treatments are indicated with *, between groups with \#. 


\section{4. $\beta$-Adrenergic Stimulation Produces Different Increase in cAMP Levels in Ctl and AF in Different Cellular Compartments}

FRET was first used to test whether the effects of ISO observed on $\mathrm{I}_{\mathrm{Ca}, \mathrm{L}}, \mathrm{Ca}^{2+}$ load, sparks and $\mathrm{I}_{\mathrm{TI}}$ were linked to cAMP compartmentalized dynamics. Thus, we transduced human isolated atrial myocytes from $\mathrm{Ctl}$ and AF patients with genetically encoded FRETbased biosensors for cytosolic cAMP (Epac1-camps), sarcolemmal cAMP (pm-Epac1) and cAMP in the vicinity of the RyR2 (Epac1-JNC). Application of ISO demonstrated that AF promotes desensitization on the $\beta$-adrenergic pathway. Figure 4a shows a significantly smaller increase in cytosolic cAMP levels upon ISO stimulation in AF myocytes compared to $\mathrm{Ctl}$ myocytes $(p<0.0001)$. Interestingly, this deregulation on cAMP levels is differentially regulated in the different cellular compartments. Contrary to the reaction in the cytosol, the increase of cAMP levels upon ISO stimulation was similar between $\mathrm{Ctl}$ and AF myocytes in the sarcolemma and the RyR2 compartments (Figure 4a).
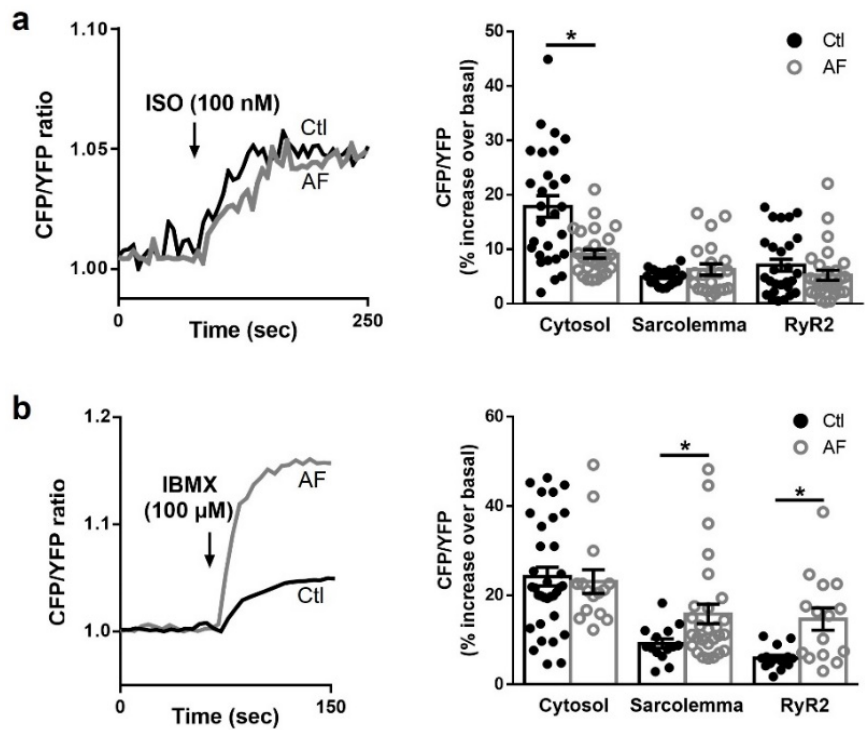

Figure 4. Cytosolic and local CAMP dynamics. (left): representative kinetics of fluorescence resonance energy transfer (FRET) changes (expressed as CFP/YFP ratio) in the ryanodine receptor (RyR2) microdomain recorded in human atrial myocytes from patients in sinus rhythm (Ctl) and with atrial fibrillation (AF), transduced with Epac1-camps-JNC sensor and treated with (a) isoproterenol (ISO, $100 \mathrm{nM}$ ) and (b) the non-selective phosphodiesterase inhibitor (IBMX, $100 \mu \mathrm{M})$ and the phosphodiesterase type 8 selective inhibitor PF-04957325 (100 nM). (right): average increases in cAMP levels in the cytosol and in different compartments (sarcolemma and RyR2) of living human atrial myocytes, measured as total cAMP produced after exposure (a) to ISO and (b) to the inhibitor IBMX. Significant differences between treatments are indicated with *.

Next, we evaluated the role of PDEs in the control of basal cytosolic and local cAMP signaling (using the genetically encoded FRET-based sensors Epac1-camps, pm-Epac1 and Epac1-JNC) by inhibiting all PDEs expressed in the atria [22] using IBMX $(100 \mu \mathrm{M})$ together with the PDE8 inhibitor PF-04957325 (100 nM), in atrial myocytes from Ctl and AF patients. Contrary to the effects elicited by ISO, application of IBMX+PF produced a similarly large increase in basal cytosolic cAMP levels by PDE inhibition in $\mathrm{Ctl}$ and in $\mathrm{AF}$ myocytes. However, IBMX+PF promoted differential increases of cAMP levels in $\mathrm{Ctl}$ versus $\mathrm{AF}$ depending on the compartment. Thus, in AF the increase of basal cAMP levels was twice as big as in $\mathrm{Ctl}$ at the sarcolemma and nearby the RyR2 (Figure 4b).

These results indicate that $\beta$-adrenergic signaling is compartmentalized by PDEs in human atrial myocytes and suggest that cAMP-dependent PKA signaling might have a prominent role regulating the phosphorylation of specific $\mathrm{Ca}^{2+}$-handling proteins, such as RyR2, in AF. 


\subsection{Carvedilol, but Not $\beta_{1}$-Blocker Treatment, Attenuates PKA Dependent Increase of $I_{T I}$ in AF}

The above results suggest that remodeling of $\beta$-adrenergic signaling in AF patients might contribute to the observed elevation of the spontaneous $\mathrm{I}_{\mathrm{TI}}$ frequency in myocytes from these patients. To further evaluate this, the effect of patients treated with $\beta$-blockers (BBs) on $\mathrm{I}_{\mathrm{Ca}, \mathrm{L}}$ density, $\mathrm{I}_{\mathrm{TI}}$ frequency and $\mathrm{SR} \mathrm{Ca}^{2+}$ load was explored. Comparing atrial myocytes from $\mathrm{Ctl}$ or AF patients who were treated with BBs and from patients who did not receive this treatment (no BBs) (Figure $5 a-c$ ), no significant difference was found on $\mathrm{I}_{\mathrm{Ca}, \mathrm{L}}$ density (Figure $5 \mathrm{a}$ ), $\mathrm{SR} \mathrm{Ca}{ }^{2+}$ load (Figure $5 \mathrm{~b}$ ), or $\mathrm{I}_{\mathrm{TI}}$ frequency (Figure $5 \mathrm{c}$ ). Statistical analysis taking into account confounding effects of concurrent disease, risk factors and other treatments different than BBs (including ACE inhibitors, angiotensin receptor blockers and amiodarone) revealed no differences in none of the tested parameters. However, separation of BBs treatment in $\beta_{1}$-blockers and Carvedilol (Figure $5 \mathrm{~d}-\mathrm{f}$ ) revealed that myocytes from AF patients who received Carvedilol treatment had reduced $\mathrm{I}_{\mathrm{TI}}$ frequency (Figure 5).

Beta blockers

a



b

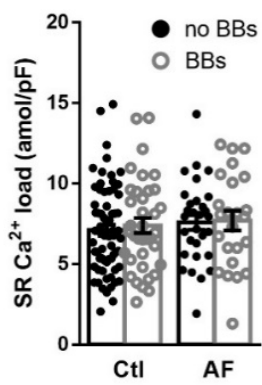

C

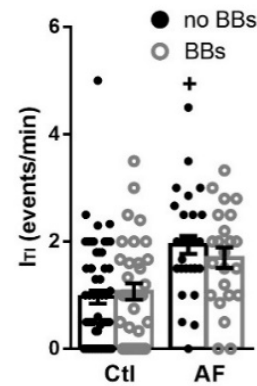

Carvedilol

d

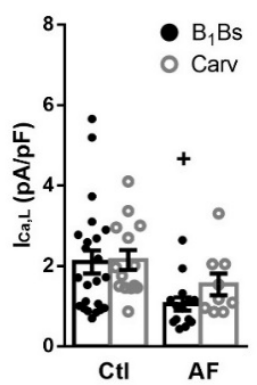

e

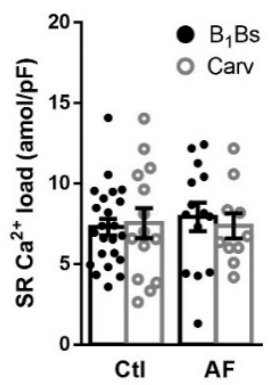

f

Figure 5. Effect of $\beta$-blocker treatment of patients on $\mathrm{Ca}^{2+}$-handling. (left): average effects of the treatment of patients with $\beta$-blockers (BBs) or without $\mathrm{BBs}$ (no BBs) on (a) $\mathrm{I}_{\mathrm{Ca}, \mathrm{L}},(\mathbf{b})$ sarcoplasmic reticulum (SR) $\mathrm{Ca}^{2+}$ load and (c) $\mathrm{I}_{\mathrm{TI}}$, in patients in sinus rhythm (Ctl) and with atrial fibrillation (AF). (right): Carvediol effects on (d) $\mathrm{I}_{\mathrm{Ca}, \mathrm{L}}$, (e) $\mathrm{SR} \mathrm{Ca}^{2+}$ load and (f) $\mathrm{I}_{\mathrm{TI}}$, in Ctl and AF. Statistical significance was evaluated using a multivariate linear regression model adjusted for the confounding effects of common clinical factors showing a bias between BBs treatment as well as factors suspected to affect $\mathrm{Ca}^{2+}$-handling. Significant differences between treatments are indicated with * and between groups with + . Each point represents a patient mean value recorded in myocytes from a total of 53 patients with AF and 104 patients without AF. 23 of the AF patients and 37 of the no AF patients were treated with BBs. 


\section{Discussion}

Our study shows that AF is associated with (1) a cAMP/PKA-dependent reduction of the $\mathrm{I}_{\mathrm{Ca}, \mathrm{L}}$ density, (2) the upregulation of cAMP/PKA-dependent stimulation of $\mathrm{SR} \mathrm{Ca}^{2+}$ release events large enough to produce $\mathrm{I}_{\mathrm{TI}}$, and 3) PDE-dependent specific cAMP signaling in each relevant compartment for $\mathrm{Ca}^{2+}$-handling regulation. While inhibition of CaMKII reduced $\mathrm{Ca}^{2+}$ sparks frequency, it did not reduce $\mathrm{I}_{\mathrm{TI}}$ frequency in myocytes from patients with AF. Furthermore, Carvedilol, but not $\beta_{1}$-blockers, strongly reduced the $\mathrm{I}_{\mathrm{TI}}$ frequency. Together our findings suggest that cAMP/PKA-dependent compartmentalized signaling has a potential to prevent large proarrhythmic $\mathrm{SR} \mathrm{Ca}^{2+}$ release events and/or increase $\mathrm{I}_{\mathrm{Ca}, \mathrm{L}}$ density in $\mathrm{AF}$ and that Carvedilol, but not $\beta_{1}$-blockers, may be a new therapeutic strategy to reduce $\mathrm{Ca}^{2+}$ release-induced atrial arrhythmias.

\subsection{PKA-Dependent Modulation of $\mathrm{Ca}^{2+}$ Homeostasis in $\mathrm{AF}$}

In line with previous studies $[2,6,23]$ atrial myocytes from patients with $\mathrm{AF}$ showed a marked reduction in $\mathrm{I}_{\mathrm{Ca}, \mathrm{L}}$ density. Although different mechanisms have been proposed to explain this reduction, i.e., reduced channel expression [24,25], redox modulation [26], or phosphatase 2-mediated dephosphorylation [11], none of them fully clarify this phenomenon. Here we show that PKA-inhibition had almost no effect on $\mathrm{I}_{\mathrm{Ca}, \mathrm{L}}$ density in AF myocytes while significantly reducing $\mathrm{I}_{\mathrm{Ca}, \mathrm{L}}$ density in Ctl myocytes (Figure 1a), suggesting that L-type $\mathrm{Ca}^{2+}$ channels were already dephosphorylated in AF. However, given that ISO had similar relative effects on the $\mathrm{I}_{\mathrm{Ca}, \mathrm{L}}$ density in myocytes from patients with and without $\mathrm{AF}$, a down-regulation of L-type $\mathrm{Ca}^{2+}$-channel expression and/or changes in the redox state of the $\mathrm{Ca}^{2+}$ channel are also likely in AF.

PKA- $[3,5,6]$ as well as CaMKII- $[6,10]$ mediated RyR2 hyperphosphorylation has been associated with the increased RyR2 activity in AF patients. Voigt et al. [6] also found significantly higher cAMP levels in right atrial samples from patients with AF than those from patients in sinus rhythm. In accordance with these findings, our study found a stronger effect of the PKA-inhibitor $\mathrm{H}-89$ on the $\mathrm{I}_{\mathrm{TI}}$ frequency in AF than in Ctl myocytes (Figure 1c), as well as a smaller relative effect of $\beta$-adrenergic stimulation with ISO in AF (Figure 3c). Together, these results highlight the role of the cAMP-dependent PKA mediated stimulation of RyR2 activity and abnormal depolarization in AF.

Hyperphosphorylation of the RyR2 has been associated with heart failure $[27,28]$ and treatment with BBs reduces RyR2 phosphorylation [28] and improves $\mathrm{Ca}^{2+}$-handling in these patients. However, in our study the $\mathrm{I}_{\mathrm{TI}}$ frequency did not differ in AF myocytes from patients with or without BBs treatment (Figure 5c), suggesting that BBs treatment had no protective effect on those patients. Importantly, Carvedilol treatment had reduced $\mathrm{I}_{\mathrm{TI}}$ frequency, indicating that BBs negative results were not due to a wash-out effect of the myocytes isolation. Although the selective effect of Carvedilol on the $\mathrm{I}_{\mathrm{TI}}$ frequency could be due to its ability to inhibit $\beta$-adrenergic receptors [28], to modify RyR2 gating [29,30] or to prevent RyR2 oxidation [31], it is the only BB capable of reducing $\mathrm{Ca}^{2+}$ waves [27]. By contrast, myocytes from patients treated with $\mathrm{B}_{1}$ Bs showed no changes in $\mathrm{I}_{\mathrm{Ca}, \mathrm{L}}$ density, $\mathrm{SR} \mathrm{Ca}^{2+}$ load or $\mathrm{I}_{\mathrm{TI}}$ frequency. These observations provide a mechanistic explanation for clinical studies showing that the treatment with Carvedilol, but not $\mathrm{B}_{1} \mathrm{Bs}$, reduces the incidence of post-operative AF [32-35] and ischemia-induced arrhythmia [34]. In line with this, we here show that PKA inhibition effectively reduces spontaneous $\mathrm{I}_{\mathrm{TI}}$, suggesting that this may be a key to preventing atrial arrhythmias where abnormal $\mathrm{Ca}^{2+}$ release is an underlying mechanism.

\subsection{CaMKII-Dependent Regulation of $\mathrm{Ca}^{2+}$ Sparks in AF}

Hyperphosphorylation of the RyR2 mediated by CaMKII has also been linked to the increased RyR2 activity seen in AF [3,6,36-41] and has been proposed as a key mechanism underlying the elevation of spontaneous $\mathrm{Ca}^{2+}$ release in AF. In agreement with these studies, we found that CaMKII inhibition significantly reduced the $\mathrm{Ca}^{2+}$ sparks frequency, although we found no significant effects on $\mathrm{I}_{\mathrm{TI}}$ frequency in $\mathrm{AF}$ nor $\mathrm{Ctl}$ myocytes. Of 
note, none of the previous studies evaluated the effect of CaMKII inhibition in human atrial myocytes on $\mathrm{Ca}^{2+}$ waves frequency, only on $\mathrm{Ca}^{2+}$ sparks frequency, $\mathrm{Ca}^{2+}$ leak or RyR2 open probability. Furthermore, although CaMKII was previously highlighted as responsible for the observed effects on $\mathrm{Ca}^{2+}$-handling, many of those studies also found a decrease in RyR2 phosphorylation (total and at Ser2808), in incidence of spontaneous $\mathrm{Ca}^{2+}$ events and in the corresponding delayed afterdepolarizations when PKA was inhibited. Our findings demonstrate that a reduction of $\mathrm{Ca}^{2+}$ sparks or passive $\mathrm{SR} \mathrm{Ca}^{2+}$ leak that had no effect on the resting membrane potential does not necessarily imply a reduction of large $\mathrm{Ca}^{2+}$ waves which induce a transient inward current and membrane depolarizations (Figure $2 b, c)$. In line with this observation, it has been shown that VK-II-86, a minimally- $\beta$ blocking Carvedilol analog, reduces arrhythmias by suppressing $\mathrm{Ca}^{2+}$ waves and RyR2 open duration but increases $\mathrm{Ca}^{2+}$ sparks frequency [29]. Furthermore, knocking out phospholamban in heterozygous R4496C mice strongly increases $\mathrm{Ca}^{2+}$ sparks but reduces cell-wide $\mathrm{Ca}^{2+}$ waves preventing ventricular arrhythmia in these mice [42].

\subsection{Key $\mathrm{Ca}^{2+}$-Handling Compartments Are Regulated by Specific cAMP Microdomains}

The observed concurrent decrease in L-type $\mathrm{Ca}^{2+}$ channel phosphorylation and hyperphosphorylation of most of RyR2 in AF suggests compartmentation of cAMP/PKA signals in restricted microdomains separately regulating the phosphorylation of each $\mathrm{Ca}^{2+}$-handling compartment. Up to date, the majority of studies on cAMP compartmentation and the effects of PDE inhibition have been performed on ventricular cells and mostly in animal models [18,43-48], and only a few studies evaluated the contribution of cAMP/PKA compartmentation on AF pathophysiology. Increased cAMP activity [6], as well as decreased total cAMP hydrolytic activity and PDE-dependent modulation of cytosolic cAMP levels $[14,15]$ were described in AF. Stimulation of both 5-HT [15,22,49] and adenosine $\mathrm{A}_{2 \mathrm{~A}}$ receptors $[5,50]$ has been linked to arrhythmias by increasing cAMP and its RyR2-dependent activation [4]. Decreased PDE activity could explain the loss in persistent AF of PDE3/PDE4 control on the propensity of 5-HT-evoked arrhythmias observed in human atrial trabeculae from patients in sinus rhythm [22]. PDE1a, PDE1c, PDE2a, PDE3a, PDE3b, PDE4a, PDE4b, PDE4d and PDE8a were found to be expressed in human atria [51]. Pharmacological inhibition of PDE4 in Ctl patients increased $\mathrm{Ca}^{2+}$ sparks and waves frequency, $\mathrm{I}_{\mathrm{Ca}, \mathrm{L}}$ and arrhythmias [14]. However, PDEs redistribution could increase their influence on cAMP signals in discrete $\mathrm{Ca}^{2+}$-handling compartments in AF. Thus, although PDE4 activity is reduced in AF, this PDE was suggested to be, at least in part, responsible for the enhanced frequency of spontaneous $\mathrm{SR} \mathrm{Ca}^{2+}$ release in AF $[14,52]$. Moreover, PDE4 inhibition increased the incidence of arrhythmias in human atrial strips during $\beta$-adrenergic stimulation [14].

Our FRET experiments to directly measure cAMP levels in living atrial myocytes from $\mathrm{Ctl}$ and $\mathrm{AF}$ patients demonstrated that although cytosolic cAMP levels increased less in AF compared to Ctl upon ISO stimulation, they are differentially regulated in the different $\mathrm{Ca}^{2+}$-handling compartments (Figure 4a). Indeed, cAMP/PKA signals can reach L-type $\mathrm{Ca}^{2+}$ channels to the same extent in $\mathrm{AF}$ as in $\mathrm{Ctl}$ myocytes upon $\beta$-adrenergic stimulation, providing an explanation to the same relative effect on the $\mathrm{I}_{\mathrm{Ca}, \mathrm{L}}$ density upon ISO stimulation in myocytes from the two groups of patients. Furthermore, inhibition of all PDEs increased basal levels of cAMP nearby L-type $\mathrm{Ca}^{2+}$ channels twice as much in AF compared to Ctl (Figure $4 \mathrm{~b}$ ), suggesting that PDEs may be responsible for the dephosphorylation of the L-type $\mathrm{Ca}^{2+}$ channel, reducing $\mathrm{I}_{\mathrm{Ca}, \mathrm{L}}$ in $\mathrm{AF}$.

At the same time, a larger increase on basal cAMP after PDE inhibition nearby RyR2 in AF (Figure 4b) would suggest an increase of PDEs in this compartment and thus, a reduction of cAMP-dependent PKA phosphorylation of these receptors. Within the hyperphosphorylated context of AF, the increase in CaMKII phosphorylation of RyR2, would maintain $\mathrm{SR} \mathrm{Ca}^{2+}$ load by increasing $\mathrm{Ca}^{2+}$ sparks and $\mathrm{SR} \mathrm{Ca}^{2+}$ leak avoiding proarrhythmic effects of $\mathrm{Ca}^{2+}$ waves and $\mathrm{I}_{\mathrm{TI}}$, which at least at a certain point of the AF progression would 
need to be accompanied by an attempted restriction of the strong PKA phosphorylation by PDEs in this compartment.

\section{Conclusions}

Many conditions, such as catecholaminergic polymorphic ventricular tachycardia (CPVT), heart failure (HF), and AF, have been linked to abnormal SR $\mathrm{Ca}^{2+}$ release and increased phosphorylation of the RyR2 $[3,5,27,28]$. Additionally, BBs have been reported to reduce RyR2 phosphorylation in CPVT and HF $[28,53]$. Here we show that selective PKA inhibition effectively reduces spontaneous $\mathrm{SR} \mathrm{Ca}^{2+}$ release in myocytes from patients with AF without affecting $\mathrm{Ca}^{2+}$ entry via L-type $\mathrm{Ca}^{2+}$ channels, therefore highlighting modulation of PKA activity as a potential key target to prevent atrial arrhythmia where abnormal $\mathrm{Ca}^{2+}$-release is an underlying mechanism. In line with this finding, spontaneous $\mathrm{SR} \mathrm{Ca}^{2+}$ release was significantly reduced in patients treated with Carvedilol, the only BB capable of reducing SR $\mathrm{Ca}^{2+}$ waves [29].

In conclusion, our results show that cAMP-dependent PKA signaling is highly compartmentalized and regulated by PDEs, that PKA inhibition effectively reduces spontaneous $\mathrm{SR} \mathrm{Ca}^{2+}$ release in $\mathrm{AF}$, and that Carvedilol treatment reduces the incidence of spontaneous $\mathrm{Ca}^{2+}$ release events and $\mathrm{I}_{\mathrm{TI}}$ in myocytes from patients with AF.

Furthermore, increasing evidence indicates that $\beta$-adrenergic signaling can activate different pathways other than PKA. Thus, $\beta$-adrenergic stimulation can also activate CaMKII via cAMP in a PKA-independent (activating Epac, nitric oxide synthase 1 and protein kinase G) [54-56] pathway, increasing $\mathrm{Ca}^{2+}$ sparks frequency and diminishing $\mathrm{Ca}^{2+}$ sparks amplitude, while decreasing SR Ca${ }^{2+}$ load [54]. In line with this observation, it has been shown that Carvedilol reduces arrhythmias by suppressing $\mathrm{Ca}^{2+}$ waves and RyR2 open duration but increasing $\mathrm{Ca}^{2+}$ sparks frequency [29]. Interestingly, we found increased expression of Epac2 in AF [51], the Epac isoform which is highly concentrated at $\mathrm{Z}$ lines and thus implicated in SR $\mathrm{Ca}^{2+}$-handling [57]. In this study, we propose a model where PKA and CaMKII phosphorylation complement each other in order to adapt $\mathrm{Ca}^{2+}$ handling to AF remodeling progression. CaMKII would enhance RyR2 phosphorylation at the dyadic clefts during the first episodes of $\mathrm{AF}$ or at the beginning of the progression of the arrhythmia increasing SR Ca ${ }^{2+}$ leak as an attempt to reduce SR $\mathrm{Ca}^{2+}$ load. A similar mechanism was proposed by Zhou et al. [29], and Díaz et al. [58], as well as in response to sudden increases in heart rate, adrenergic stress or stimulation in normal hearts [59-63]. However, and in line with previous CaMKII studies regarding its affinity and RyR2 $\mathrm{Ca}^{2+}$ sensitivity [63-65], during diseases such as persistent AF with chronic adrenergic stimulation, enhanced cytosolic and dedicated CaMKII activity would worsen the effects of PKA-hyperphosphorylation by contributing to abnormal diastolic $\mathrm{Ca}^{2+}$ release from the SR, and triggering arrhythmias.

Although in atrial myocytes, L-type $\mathrm{Ca}^{2+}$ channels (LTCC) are equally distributed in and out of the tubular system [66], AF-associated cell hypertrophy and structural changes in the sarcolemma and RyR2 microdomains $[67,68]$ may affect LTCC function, $\mathrm{Ca}^{2+}{ }_{\text {-induced }}$ $\mathrm{Ca}^{2+}$-release events, RyR2 coupling to LTCC, PDE microdomains, RyR2 $\mathrm{Ca}^{2+}$ sensitivity and CaMKII activity. Further investigation regarding how structural changes in AF remodeling affect PKA, CaMKII and PDE interactions in basal and during $\beta$-adrenergic stimulation would provide valuable insights into AF pathophysiology.

\section{Study Limitations}

Due to the isolation process potentially washing out acute effects of BB treatment, this study could only confirm long-term effects of $\mathrm{BBs}$ on the remodeling of $\mathrm{Ca}^{2+}$ handling in atrial myocytes. However, the exclusion of patients who received concomitant treatment that theoretically could mask any BB effects did not alter our results.

Several reasons, such as differences in patient cohort or in experimental conditions, could account for the discrepancies between this and previous studies. Usage of the perforated patch-clamp technique in the present study, preserving cAMP-dependent sig- 
naling, compared to using the ruptured patch-clamp technique which has been reported to attenuate cAMP-dependent signaling and removes the effects observed on $\mathrm{I}_{\mathrm{Ca}, \mathrm{L}}$ during perforated-patch recordings [40], is likely an important factor, as any interference in cAMPdependent signaling could bias towards CaMKII-dependent signaling. The present study used a physiological $\mathrm{Ca}^{2+}$ concentration $(2 \mathrm{mM})$ rather than a high $\mathrm{Ca}^{2+}$ concentration $(5 \mathrm{mM})$, commonly used to increase SR $\mathrm{Ca}^{2+}$ release events, and which would produce an overestimation of CaMKII-dependent signaling.

Supplementary Materials: The following are available online at https:/ /www.mdpi.com/article/ 10.3390/cells10113042/s1, Figure S1: Effects of H-89, isoproterenol (ISO) and $\mathrm{Ca}^{2+} /$ Calmodulindependent protein kinase II (CaMKII) inhibition with KN-92 and KN-93 on ITI amplitude. Average effects of protein kinase A (PKA) inhibition with H-89 (top left panel), PKA stimulation with ISO (top right panel), and CaMKII inhibition (bottom panel) with KN-92 (the inactive CaMKII inhibitor) and $\mathrm{KN}-93$ in sinus rhythm (Ctl) and atrial fibrillation (AF) patients. Significant differences between treatments are indicated with * and between groups with +, Figure S2: Effects of $\mathrm{Ca}^{2+} /$ Calmodulindependent protein kinase II (CaMKII) inhibition on sarcoplasmic reticulum (SR) $\mathrm{Ca}^{2+}$ load. Average effect of CaMKII inhibition with KN-92 (the inactive CaMKII inhibitor) and KN-93 on SR Ca ${ }^{2+}$ load in sinus rhythm $(\mathrm{Ctl})$ and atrial fibrillation (AF). Significant differences between treatments are indicated with *.

Author Contributions: Conceptualization, C.E.M. and L.H.-M.; investigation, F.R., K.B. and N.G.P.; resources, L.C. and H.R.; writing—original draft preparation, K.B. and C.E.M.; supervision, C.E.M.; funding acquisition, C.E.M. All authors have read and agreed to the published version of the manuscript.

Funding: This work was supported by the Deutsche Forschungsgemeinschaft (ES 569/2-1 to CM) and the German Centre for Cardiovascular Research (DZHK), Spanish Ministry of Science and Innovation (PID2020-116927RB-C21 to L.H-M).

Institutional Review Board Statement: The study was conducted in accordance with the Declaration of Helsinki principles and approved by the Ethical Committees of the Universitätsklinikum HamburgEppendorf, Germany (Ethical approval Number: WF-088/18).

Informed Consent Statement: Informed consent was obtained from all subjects involved in the study.

Data Availability Statement: The data presented in this study are available on request from the corresponding author.

Acknowledgments: We thank the UKE Microscopy Imaging Facility (UMIF, University Medical Center Hamburg-Eppendorf) for technical support and providing the Leica TCS SP8 X microscope.

Conflicts of Interest: The authors declare no conflict of interest.

\section{References}

1. Hove-Madsen, L.; Llach, A.; Bayes-Genís, A.; Roura, S.; Font, E.R.; Arís, A.; Cinca, J. Atrial Fibrillation Is Associated with Increased Spontaneous Calcium Release From the Sarcoplasmic Reticulum in Human Atrial Myocytes. Circulation 2004, 110, 1358-1363. [CrossRef]

2. van Wagoner, D.R.; Pond, A.L.; Lamorgese, M.; Rossie, S.S.; McCarthy, P.M.; Nerbonne, J.M. Atrial L-Type Ca ${ }^{2+}$ Currents and Human Atrial Fibrillation. Circ. Res. 1999, 85, 428-436. [CrossRef]

3. Vest, J.A.; Wehrens, X.H.T.; Reiken, S.R.; Lehnart, S.E.; Dobrev, D.; Chandra, P.; Danilo, P.; Ravens, U.; Rosen, M.R.; Marks, A.R. Defective Cardiac Ryanodine Receptor Regulation during Atrial Fibrillation. Circulation 2005, 111, 2025-2032. [CrossRef] [PubMed]

4. Beneke, K.; Molina, C.E. Molecular Basis of Atrial Fibrillation Initiation and Maintenance. Hearts 2021, 2, 14. [CrossRef]

5. Llach, A.; Molina, C.E.; Prat-Vidal, C.; Fernandes, J.; Casado, V.; Ciruela, F.; Lluis, C.; Franco, R.; Cinca, J.; Hove-Madsen, L. Abnormal Calcium Handling in Atrial Fibrillation Is Linked to Up-Regulation of Adenosine A2A Receptors. Eur. Heart J. 2011, 32, 721-729. [CrossRef] [PubMed]

6. Voigt, N.; Li, N.; Wang, Q.; Wang, W.; Trafford, A.W.; Abu-Taha, I.; Sun, Q.; Wieland, T.; Ravens, U.; Nattel, S.; et al. Enhanced Sarcoplasmic Reticulum $\mathrm{Ca}^{2+}$ Leak and Increased $\mathrm{Na}+-\mathrm{Ca}^{2+}$ Exchanger Function Underlie Delayed Afterdepolarizations in Patients with Chronic Atrial Fibrillation. Circulation 2012, 125, 2059-2070. [CrossRef] [PubMed] 
7. Llach, A.; Molina, C.E.; Fernandes, J.; Padró, J.; Cinca, J.; Hove-Madsen, L. Sarcoplasmic Reticulum and L-Type Ca ${ }^{2+}$ Channel Activity Regulate the Beat-to-Beat Stability of Calcium Handling in Human Atrial Myocytes. J. Physiol. 2011, 589, $3247-3262$. [CrossRef]

8. Dinanian, S.; Boixel, C.; Juin, C.; Hulot, J.-S.; Coulombe, A.; Rücker-Martin, C.; Bonnet, N.; le Grand, B.; Slama, M.; Mercadier, J.-J.; et al. Downregulation of the Calcium Current in Human Right Atrial Myocytes from Patients in Sinus Rhythm but with a High Risk of Atrial Fibrillation. Eur. Heart J. 2008, 29, 1190-1197. [CrossRef]

9. El-Armouche, A.; Boknik, P.; Eschenhagen, T.; Carrier, L.; Knaut, M.; Ravens, U.; Dobrev, D. Molecular Determinants of Altered $\mathrm{Ca}^{2+}$ Handling in Human Chronic Atrial Fibrillation. Circulation 2006, 114, 670-680. [CrossRef] [PubMed]

10. Neef, S.; Dybkova, N.; Sossalla, S.; Ort, K.R.; Fluschnik, N.; Neumann, K.; Seipelt, R.; SchÖndube, F.A.; Hasenfuss, G.; Maier, L.S. CaMKII-Dependent Diastolic SR Ca ${ }^{2+}$ Leak and Elevated Diastolic $\mathrm{Ca}^{2+}$ Levels in Right Atrial Myocardium of Patients with Atrial Fibrillation. Circ. Res. 2010, 106, 1134-1144. [CrossRef] [PubMed]

11. Christ, T.; Boknik, P.; WÖhrl, S.; Wettwer, E.; Graf, E.M.; Bosch, R.F.; Knaut, M.; Schmitz, W.; Ravens, U.; Dobrev, D. L-Type Ca ${ }^{2+}$ Current Downregulation in Chronic Human Atrial Fibrillation Is Associated with Increased Activity of Protein Phosphatases. Circulation 2004, 110, 2651-2657. [CrossRef]

12. de Rooij, J.; Zwartkruis, F.J.T.; Verheijen, M.H.G.; Cool, R.H.; Nijman, S.M.B.; Wittinghofer, A.; Bos, J.L. Epac Is a Rap1 GuanineNucleotide-Exchange Factor Directly Activated by Cyclic AMP. Nature 1998, 396, 474-477. [CrossRef]

13. Pereira, L.; Métrich, M.; Fernández-Velasco, M.; Lucas, A.; Leroy, J.; Perrier, R.; Morel, E.; Fischmeister, R.; Richard, S.; Bénitah, J.-P.; et al. The CAMP Binding Protein Epac Modulates $\mathrm{Ca}^{2+}$ Sparks by a $\mathrm{Ca}^{2+} /$ Calmodulin Kinase Signalling Pathway in Rat Cardiac Myocytes. J. Physiol. 2007, 583, 685-694. [CrossRef] [PubMed]

14. Molina, C.E.; Leroy, J.; Richter, W.; Xie, M.; Scheitrum, C.; Lee, I.-O.; Maack, C.; Rucker-Martin, C.; Donzeau-Gouge, P.; Verde, I.; et al. Cyclic Adenosine Monophosphate Phosphodiesterase Type 4 Protects Against Atrial Arrhythmias. J. Am. Coll. Cardiol. 2012, 59, 2182-2190. [CrossRef]

15. Dolce, B.; Christ, T.; Grammatika Pavlidou, N.; Yildirim, Y.; Reichenspurner, H.; Eschenhagen, T.; Nikolaev, V.O.; Kaumann, A.J.; Molina, C.E. Impact of Phosphodiesterases PDE3 and PDE4 on 5-Hydroxytryptamine Receptor4-Mediated Increase of CAMP in Human Atrial Fibrillation. Naunyn-Schmiedeberg's Arch. Pharmacol. 2020, 394, 291-298. [CrossRef]

16. Hove-Madsen, L.; Llach, A.; Molina, C.E.; Prat-Vidal, C.; Farré, J.; Roura, S.; Cinca, J. The Proarrhythmic Antihistaminic Drug Terfenadine Increases Spontaneous Calcium Release in Human Atrial Myocytes. Eur. J. Pharmacol. 2006, 553, 215-221. [CrossRef] [PubMed]

17. Cheng, H.; Song, L.-S.; Shirokova, N.; González, A.; Lakatta, E.G.; Ríos, E.; Stern, M.D. Amplitude Distribution of Calcium Sparks in Confocal Images: Theory and Studies with an Automatic Detection Method. Biophys. J. 1999, 76, 606-617. [CrossRef]

18. Bastug-Özel, Z.; Wright, P.T.; Kraft, A.E.; Pavlovic, D.; Howie, J.; Froese, A.; Fuller, W.; Gorelik, J.; Shattock, M.J.; Nikolaev, V.O. Heart Failure Leads to Altered B2-Adrenoceptor/Cyclic Adenosine Monophosphate Dynamics in the Sarcolemmal Phospholemman/Na,K ATPase Microdomain. Cardiovasc. Res. 2019, 115, 546-555. [CrossRef]

19. Wright, P.T.; Bhogal, N.K.; Diakonov, I.; Pannell, L.M.K.; Perera, R.K.; Bork, N.I.; Schobesberger, S.; Lucarelli, C.; Faggian, G.; Alvarez-Laviada, A.; et al. Cardiomyocyte Membrane Structure and CAMP Compartmentation Produce Anatomical Variation in B2AR-CAMP Responsiveness in Murine Hearts. Cell Rep. 2018, 23, 459-469. [CrossRef]

20. Berisha, F.; Götz, K.R.; Wegener, J.W.; Brandenburg, S.; Subramanian, H.; Molina, C.E.; Rüffer, A.; Petersen, J.; Bernhardt, A.; Girdauskas, E.; et al. CAMP Imaging at Ryanodine Receptors Reveals $\beta_{2}$-Adrenoceptor Driven Arrhythmias. Circ. Res. 2021, 129. [CrossRef] [PubMed]

21. Edelstein, A.D.; Tsuchida, M.A.; Amodaj, N.; Pinkard, H.; Vale, R.D.; Stuurman, N. Advanced Methods of Microscope Control Using MManager Software. J. Biol. Methods 2014, 1, e10. [CrossRef] [PubMed]

22. Berk, E.; Christ, T.; Schwarz, S.; Ravens, U.; Knaut, M.; Kaumann, A.J. In Permanent Atrial Fibrillation, PDE3 Reduces Force Responses to 5-HT, but PDE3 and PDE4 Do Not Cause the Blunting of Atrial Arrhythmias. Br. J. Pharmacol. 2016, 173, 2478-2489. [CrossRef] [PubMed]

23. Llach, A.; Molina, C.E.; Alvarez-Lacalle, E.; Tort, L.; Benítez, R.; Hove-Madsen, L. Detection, Properties, and Frequency of Local Calcium Release from the Sarcoplasmic Reticulum in Teleost Cardiomyocytes. PLoS ONE 2011, 6, e23708. [CrossRef]

24. Gaborit, N.; Steenman, M.; Lamirault, G.; le Meur, N.; le Bouter, S.; Lande, G.; Líger, J.; Charpentier, F.; Christ, T.; Dobrev, D.; et al. Human Atrial Ion Channel and Transporter Subunit Gene-Expression Remodeling Associated With Valvular Heart Disease and Atrial Fibrillation. Circulation 2005, 112, 471-481. [CrossRef]

25. Lai, L.-P.; Su, M.-J.; Lin, J.-L.; Lin, F.-Y.; Tsai, C.-H.; Chen, Y.-S.; Huang, S.K.S.; Tseng, Y.-Z.; Lien, W.-P. Down-Regulation of L-Type Calcium Channel and Sarcoplasmic Reticular $\mathrm{Ca}^{2+}$-ATPase MRNA in Human Atrial Fibrillation without Significant Change in the MRNA of Ryanodine Receptor, Calsequestrin and Phospholamban. J. Am. Coll. Cardiol. 1999, 33, 1231-1237. [CrossRef]

26. Carnes, C.A.; Janssen, P.M.L.; Ruehr, M.L.; Nakayama, H.; Nakayama, T.; Haase, H.; Bauer, J.A.; Chung, M.K.; Fearon, I.M.; Gillinov, A.M.; et al. Atrial Glutathione Content, Calcium Current, and Contractility. J. Biol. Chem. 2007, 282, 28063-28073. [CrossRef]

27. Marx, S.O.; Reiken, S.; Hisamatsu, Y.; Jayaraman, T.; Burkhoff, D.; Rosemblit, N.; Marks, A.R. PKA Phosphorylation Dissociates FKBP12.6 from the Calcium Release Channel (Ryanodine Receptor). Cell 2000, 101, 365-376. [CrossRef] 
28. Reiken, S.; Wehrens, X.H.T.; Vest, J.A.; Barbone, A.; Klotz, S.; Mancini, D.; Burkhoff, D.; Marks, A.R. $\beta$-Blockers Restore Calcium Release Channel Function and Improve Cardiac Muscle Performance in Human Heart Failure. Circulation 2003, 107, $2459-2466$. [CrossRef] [PubMed]

29. Zhou, Q.; Xiao, J.; Jiang, D.; Wang, R.; Vembaiyan, K.; Wang, A.; Smith, C.D.; Xie, C.; Chen, W.; Zhang, J.; et al. Carvedilol and Its New Analogs Suppress Arrhythmogenic Store Overload-Induced Ca ${ }^{2+}$ Release. Nat. Med. 2011, 17, 1003-1009. [CrossRef]

30. Martinez-Hernandez, E.; Blatter, L.A. Effect of Carvedilol on Atrial Excitation-Contraction Coupling, Ca ${ }^{2+}$ Release, and Arrhythmogenicity. Am. J. Physiol.-Heart Circ. Physiol. 2020, 318, H1245-H1255. [CrossRef]

31. Mochizuki, M.; Yano, M.; Oda, T.; Tateishi, H.; Kobayashi, S.; Yamamoto, T.; Ikeda, Y.; Ohkusa, T.; Ikemoto, N.; Matsuzaki, M. Scavenging Free Radicals by Low-Dose Carvedilol Prevents Redox-Dependent $\mathrm{Ca}^{2+}$ Leak Via Stabilization of Ryanodine Receptor in Heart Failure. J. Am. Coll. Cardiol. 2007, 49, 1722-1732. [CrossRef] [PubMed]

32. Merritt, J.C.; Niebauer, M.; Tarakji, K.; Hammer, D.; Mills, R.M. Comparison of Effectiveness of Carvedilol versus Metoprolol or Atenolol for Atrial Fibrillation Appearing after Coronary Artery Bypass Grafting or Cardiac Valve Operation. Am. J. Cardiol. 2003, 92, 735-736. [CrossRef]

33. Ozaydin, M.; Icli, A.; Yucel, H.; Akcay, S.; Peker, O.; Erdogan, D.; Varol, E.; Dogan, A.; Okutan, H. Metoprolol vs. Carvedilol or Carvedilol plus N-Acetyl Cysteine on Post-Operative Atrial Fibrillation: A Randomized, Double-Blind, Placebo-Controlled Study. Eur. Heart J. 2013, 34, 597-604. [CrossRef] [PubMed]

34. Acikel, S.; Bozbas, H.; Gultekin, B.; Aydinalp, A.; Saritas, B.; Bal, U.; Yildirir, A.; Muderrisoglu, H.; Sezgin, A.; Ozin, B. Comparison of the Efficacy of Metoprolol and Carvedilol for Preventing Atrial Fibrillation after Coronary Bypass Surgery. Int. J. Cardiol. 2008, 126, 108-113. [CrossRef] [PubMed]

35. Gheorghiade, M.; Robbins, J.D.; Lukas, M.A. Role of Carvedilol in Atrial Fibrillation: Insights from Clinical Trials. Am. J. Cardiol. 2004, 93, 53-57. [CrossRef] [PubMed]

36. Neefs, J.; van den Berg, N.W.E.; Limpens, J.; Berger, W.R.; Boekholdt, S.M.; Sanders, P.; de Groot, J.R. Aldosterone Pathway Blockade to Prevent Atrial Fibrillation: A Systematic Review and Meta-Analysis. Int. J. Cardiol. 2017, 231, 155-161. [CrossRef]

37. Pabel, S.; Mustroph, J.; Stehle, T.; Lebek, S.; Dybkova, N.; Keyser, A.; Rupprecht, L.; Wagner, S.; Neef, S.; Maier, L.S.; et al. Dantrolene Reduces CaMKIIIC-Mediated Atrial Arrhythmias. EP Eur. 2020, 22, 1111-1118. [CrossRef]

38. Voigt, N.; Heijman, J.; Wang, Q.; Chiang, D.Y.; Li, N.; Karck, M.; Wehrens, X.H.T.; Nattel, S.; Dobrev, D. Cellular and Molecular Mechanisms of Atrial Arrhythmogenesis in Patients with Paroxysmal Atrial Fibrillation. Circulation 2014, 129, 145-156. [CrossRef]

39. Heijman, J.; Muna, A.P.; Veleva, T.; Molina, C.E.; Sutanto, H.; Tekook, M.; Wang, Q.; Abu-Taha, I.H.; Gorka, M.; Künzel, S.; et al. Atrial Myocyte NLRP3/CaMKII Nexus Forms a Substrate for Postoperative Atrial Fibrillation. Circ. Res. 2020, 127, $1036-1055$. [CrossRef] [PubMed]

40. Chelu, M.G.; Sarma, S.; Sood, S.; Wang, S.; van Oort, R.J.; Skapura, D.G.; Li, N.; Santonastasi, M.; Müller, F.U.; Schmitz, W.; et al. Calmodulin Kinase II-Mediated Sarcoplasmic Reticulum Ca ${ }^{2+}$ Leak Promotes Atrial Fibrillation in Mice. J. Clin. Investig. 2009, 119, 1940-1951. [CrossRef]

41. Molina, C.E.; Abu-Taha, I.H.; Wang, Q.; Roselló-Díez, E.; Kamler, M.; Nattel, S.; Ravens, U.; Wehrens, X.H.T.; Hove-Madsen, L.; Heijman, J.; et al. Profibrotic, Electrical, and Calcium-Handling Remodeling of the Atria in Heart Failure Patients With and Without Atrial Fibrillation. Front. Physiol. 2018, 9, 1383. [CrossRef]

42. Bai, Y.; Jones, P.P.; Guo, J.; Zhong, X.; Clark, R.B.; Zhou, Q.; Wang, R.; Vallmitjana, A.; Benitez, R.; Hove-Madsen, L.; et al. Phospholamban Knockout Breaks Arrhythmogenic $\mathrm{Ca}^{2+}$ Waves and Suppresses Catecholaminergic Polymorphic Ventricular Tachycardia in Mice. Circ. Res. 2013, 113, 517-526. [CrossRef] [PubMed]

43. Fischmeister, R.; Castro, L.R.V.; Abi-Gerges, A.; Rochais, F.; Jurevicius, J.; Leroy, J.; Vandecasteele, G. Compartmentation of Cyclic Nucleotide Signaling in the Heart. Circ. Res. 2006, 99, 816-828. [CrossRef] [PubMed]

44. Karam, S.; Margaria, J.P.; Bourcier, A.; Mika, D.; Varin, A.; Bedioune, I.; Lindner, M.; Bouadjel, K.; Dessillons, M.; Gaudin, F.; et al. Cardiac Overexpression of PDE4B Blunts $\beta$-Adrenergic Response and Maladaptive Remodeling in Heart Failure. Circulation 2020, 142, 161-174. [CrossRef]

45. Pavlaki, N.; de Jong, K.A.; Geertz, B.; Nikolaev, V.O.; Froese, A. Cardiac Hypertrophy Changes Compartmentation of CAMP in Non-Raft Membrane Microdomains. Cells 2021, 10, 535. [CrossRef]

46. Nikolaev, V.O.; Moshkov, A.; Lyon, A.R.; Miragoli, M.; Novak, P.; Paur, H.; Lohse, M.J.; Korchev, Y.E.; Harding, S.E.; Gorelik, J. Beta2-Adrenergic Receptor Redistribution in Heart Failure Changes CAMP Compartmentation. Science 2010, 327, $1653-1657$. [CrossRef] [PubMed]

47. Wagner, M.; Sadek, M.S.; Dybkova, N.; Mason, F.E.; Klehr, J.; Firneburg, R.; Cachorro, E.; Richter, K.; Klapproth, E.; Kuenzel, S.R.; et al. Cellular Mechanisms of the Anti-Arrhythmic Effect of Cardiac PDE2 Overexpression. Int. J. Mol. Sci. 2021, $22,4816$. [CrossRef]

48. Surdo, N.C.; Berrera, M.; Koschinski, A.; Brescia, M.; Machado, M.R.; Carr, C.; Wright, P.; Gorelik, J.; Morotti, S.; Grandi, E.; et al. FRET Biosensor Uncovers CAMP Nano-Domains at $\beta$-Adrenergic Targets That Dictate Precise Tuning of Cardiac Contractility. Nat. Commun. 2017, 8, 15031. [CrossRef] [PubMed]

49. Christ, T.; Rozmaritsa, N.; Engel, A.; Berk, E.; Knaut, M.; Metzner, K.; Canteras, M.; Ravens, U.; Kaumann, A. Arrhythmias, Elicited by Catecholamines and Serotonin, Vanish in Human Chronic Atrial Fibrillation. Proc. Natl. Acad. Sci. USA 2014, 111, 11193-11198. [CrossRef] 
50. Molina, C.E.; Llach, A.; Herraiz-Martínez, A.; Tarifa, C.; Barriga, M.; Wiegerinck, R.F.; Fernandes, J.; Cabello, N.; Vallmitjana, A.; Benitéz, R.; et al. Prevention of Adenosine A2A Receptor Activation Diminishes Beat-to-Beat Alternation in Human Atrial Myocytes. Basic Res. Cardiol. 2016, 111, 5. [CrossRef]

51. Garnier, A.; Bork, N.I.; Jacquet, E.; Zipfel, S.; Muñoz-Guijosa, C.; Baczkó, I.; Reichenspurner, H.; Donzeau-Gouge, P.; Maier, L.S.; Dobrev, D.; et al. Mapping Genetic Changes in the CAMP-Signaling Cascade in Human Atria. J. Mol. Cell. Cardiol. 2021, 155, 10-20. [CrossRef] [PubMed]

52. Lehnart, S.E.; Wehrens, X.H.T.; Reiken, S.; Warrier, S.; Belevych, A.E.; Harvey, R.D.; Richter, W.; Jin, S.-L.C.; Conti, M.; Marks, A.R. Phosphodiesterase 4D Deficiency in the Ryanodine-Receptor Complex Promotes Heart Failure and Arrhythmias. Cell 2005, 123, 25-35. [CrossRef] [PubMed]

53. Priori, S.G.; Napolitano, C.; Memmi, M.; Colombi, B.; Drago, F.; Gasparini, M.; DeSimone, L.; Coltorti, F.; Bloise, R.; Keegan, R.; et al. Clinical and Molecular Characterization of Patients With Catecholaminergic Polymorphic Ventricular Tachycardia. Circulation 2002, 106, 69-74. [CrossRef]

54. Pereira, L.; Cheng, H.; Lao, D.H.; Na, L.; van Oort, R.J.; Brown, J.H.; Wehrens, X.H.T.; Chen, J.; Bers, D.M. Epac2 Mediates Cardiac B1-Adrenergic-Dependent Sarcoplasmic Reticulum Ca ${ }^{2+}$ Leak and Arrhythmia. Circulation 2013, 127, 913-922. [CrossRef]

55. Curran, J.; Tang, L.; Roof, S.R.; Velmurugan, S.; Millard, A.; Shonts, S.; Wang, H.; Santiago, D.; Ahmad, U.; Perryman, M.; et al. Nitric Oxide-Dependent Activation of CaMKII Increases Diastolic Sarcoplasmic Reticulum Calcium Release in Cardiac Myocytes in Response to Adrenergic Stimulation. PLoS ONE 2014, 9, e87495. [CrossRef]

56. Gutierrez, D.A.; Fernandez-Tenorio, M.; Ogrodnik, J.; Niggli, E. NO-Dependent CaMKII Activation during $\beta$-Adrenergic Stimulation of Cardiac Muscle. Cardiovasc. Res. 2013, 100, 392-401. [CrossRef] [PubMed]

57. Pereira, L.; Rehmann, H.; Lao, D.H.; Erickson, J.R.; Bossuyt, J.; Chen, J.; Bers, D.M. Novel Epac Fluorescent Ligand Reveals Distinct Epac1 vs. Epac2 Distribution and Function in Cardiomyocytes. Proc. Natl. Acad. Sci. USA 2015, 112, 3991-3996. [CrossRef]

58. Díaz, M.E.; Trafford, A.W.; O’Neill, S.C.; Eisner, D.A. Measurement of Sarcoplasmic Reticulum Ca ${ }^{2+}$ Content and Sarcolemmal $\mathrm{Ca}^{2+}$ Fluxes in Isolated Rat Ventricular Myocytes during Spontaneous Ca ${ }^{2+}$ Release. J. Physiol. 1997, 501, 3-16. [CrossRef]

59. Wehrens, X.H.T.; Lehnart, S.E.; Reiken, S.R.; Marks, A.R. $\mathrm{Ca}^{2+} /$ Calmodulin-Dependent Protein Kinase II Phosphorylation Regulates the Cardiac Ryanodine Receptor. Circ. Res. 2004, 94, e61-e70. [CrossRef]

60. Wu, Y.; Gao, Z.; Chen, B.; Koval, O.M.; Singh, M.V.; Guan, X.; Hund, T.J.; Kutschke, W.; Sarma, S.; Grumbach, I.M.; et al. Calmodulin Kinase II Is Required for Fight or Flight Sinoatrial Node Physiology. Proc. Natl. Acad. Sci. USA 2009, 106, $5972-5977$. [CrossRef]

61. Kushnir, A.; Shan, J.; Betzenhauser, M.J.; Reiken, S.; Marks, A.R. Role of CaMKII Phosphorylation of the Cardiac Ryanodine Receptor in the Force Frequency Relationship and Heart Failure. Proc. Natl. Acad. Sci. USA 2010, 107, 10274-10279. [CrossRef] [PubMed]

62. Lebek, S.; Plößl, A.; Baier, M.; Mustroph, J.; Tarnowski, D.; Lücht, C.M.; Schopka, S.; Flörchinger, B.; Schmid, C.; Zausig, Y.; et al. The Novel CaMKII Inhibitor GS-680 Reduces Diastolic SR Ca Leak and Prevents CaMKII-Dependent pro-Arrhythmic Activity. J. Mol. Cell. Cardiol. 2018, 118, 159-168. [CrossRef]

63. Dries, E.; Santiago, D.J.; Johnson, D.M.; Gilbert, G.; Holemans, P.; Korte, S.M.; Roderick, H.L.; Sipido, K.R. Calcium/CalmodulinDependent Kinase II and Nitric Oxide Synthase 1-Dependent Modulation of Ryanodine Receptors during $\beta$-Adrenergic Stimulation Is Restricted to the Dyadic Cleft. J. Physiol. 2016, 594, 5923-5939. [CrossRef]

64. Guo, T.; Zhang, T.; Mestril, R.; Bers, D.M. Ca ${ }^{2+} /$ Calmodulin-Dependent Protein Kinase II Phosphorylation of Ryanodine Receptor Does Affect Calcium Sparks in Mouse Ventricular Myocytes. Circ. Res. 2006, 99, 398-406. [CrossRef]

65. Wood, B.M.; Simon, M.; Galice, S.; Alim, C.C.; Ferrero, M.; Pinna, N.N.; Bers, D.M.; Bossuyt, J. Cardiac CaMKII Activation Promotes Rapid Translocation to Its Extra-Dyadic Targets. J. Mol. Cell. Cardiol. 2018, 125, 18-28. [CrossRef] [PubMed]

66. Glukhov, A.V.; Balycheva, M.; Sanchez-Alonso, J.L.; Ilkan, Z.; Alvarez-Laviada, A.; Bhogal, N.; Diakonov, I.; Schobesberger, S.; Sikkel, M.B.; Bhargava, A.; et al. Direct Evidence for Microdomain-Specific Localization and Remodeling of Functional L-Type Calcium Channels in Rat and Human Atrial Myocytes. Circulation 2015, 132, 2372-2384. [CrossRef]

67. Lenaerts, I.; Bito, V.; Heinzel, F.R.; Driesen, R.B.; Holemans, P.; D’hooge, J.; Heidbuchel, H.; Sipido, K.R.; Willems, R. Ultrastructural and Functional Remodeling of the Coupling Between $\mathrm{Ca}^{2+}$ Influx and Sarcoplasmic Reticulum Ca ${ }^{2+}$ Release in Right Atrial Myocytes from Experimental Persistent Atrial Fibrillation. Circ. Res. 2009, 105, 876-885. [CrossRef] [PubMed]

68. Brandenburg, S.; Kohl, T.; Williams, G.S.B.; Gusev, K.; Wagner, E.; Rog-Zielinska, E.A.; Hebisch, E.; Dura, M.; Didié, M.; Gotthardt, M.; et al. Axial Tubule Junctions Control Rapid Calcium Signaling in Atria. J. Clin. Investig. 2016, 126, 3999-4015. [CrossRef] 